\section{UCDNN}

LIBRARY
University of Connecticut OpenCommons@UConn

Faculty Articles and Papers

School of Law

2009

\title{
Red: Racism and the American Indian
}

Bethany Berger

University of Connecticut School of Law

Follow this and additional works at: https://opencommons.uconn.edu/law_papers

Part of the Civil Rights and Discrimination Commons, and the Law and Race Commons

\section{Recommended Citation}

Berger, Bethany, "Red: Racism and the American Indian" (2009). Faculty Articles and Papers. 265.

https://opencommons.uconn.edu/law_papers/265 


\section{HEINONLINE}

Citation: 56 UCLA L. Rev. 591 2008-2009

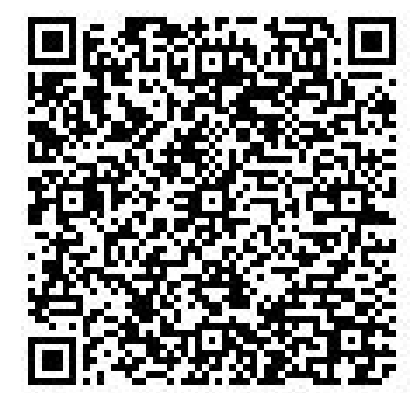

Content downloaded/printed from

HeinOnline (http://heinonline.org)

Mon Aug 15 16:42:05 2016

-- Your use of this HeinOnline PDF indicates your acceptance of HeinOnline's Terms and Conditions of the license agreement available at http://heinonline.org/HOL/License

-- The search text of this PDF is generated from uncorrected OCR text.

-- To obtain permission to use this article beyond the scope of your HeinOnline license, please use:

https://www.copyright.com/ccc/basicSearch.do?

\&operation $=$ go\&search $T y p e=0$

\&lastSearch $=$ simple\&all=on\&titleOrStdNo $=0041-5650$ 


\title{
RED: \\ RACISM AND THE AMERICAN INDIAN
}

\author{
Bethany R. Berger
}

How does racism work in American Indian law and policy? Scholarship on the subject too often has assumed that racism works for Indians in the same way that it does for African Americans, and has therefore either emphasized the presence of hallmarks of black-white racism, such as uses of blood quantum, as evidence of racism, or has emphasized the lack of such hallmarks, such as prohibitions on interracial marriage, to argue that racism is not a significant factor. This Article surveys the different eras of Indian-white interaction to argue that racism has been important in those interactions, but has worked in a distinctive way. North Americans were not primarily concerned with using Indian people as a source of labor, and therefore did not have to theorize Indians as inferior individuals to control that labor. Rather, the primary concerm was to obtain tribal resources and use tribes as a flattering foil for American society and culture. As a result, it was necessary to theorize tribal societies as fatally and racially inferior groups, while emphasizing the ability of Indian individuals to leave their societies and join non-Indian ones. This theory addresses the odd paradox that the most unquestionably racist eras in Indian-white interaction emphasized and encouraged assimilation of Indian individuals. It also contributes to the ongoing effort to understand the varying manifestations of racism in a multiracial America. Most important, it provides a new perspective on efforts to curtail tribal sovereignty in the name of racial equality, revealing their connection to historic efforts to maintain the inferiority of Indian tribes by treating them as racial groups rather than political entities with governmental rights.

INTRODUCTION

I. COMmON Origins, Divergent PATHS: COLONIAL USES OF AFRICAN

AND INDIAN RACE

A. Origins of Racial Domination

B. Evolution of Racism in the New World

C. The Rise and Demise of Indian Slavery

* Oneida Nation Visiting Professor of Indian Law, Harvard Law School; Professor of Law, University of Connecticut School of Law. Sincere thanks for comments and suggestions to Devon Carbado, Robert Clinton, Richard Collins, Philip Frickey, Rachel Godsil, Carole Goldberg, Ariela Gross, Kaaryn Gustafson, Sarah Krakoff, Jessica Litman, Jeremy Paul, Ezra Rosser, Joseph William Singer, Alexander Tallchief Skibine, Paul Spruhan, Rebecca Tsosie, and Kevin Washburn, as well as participants at the American Society for Legal History, the Law and Society Association, Arizona State University, and the Denver University-Colorado University Indian Law Works in Progress Conference. 
II. FOUNDING AND RACING THE NATION 617

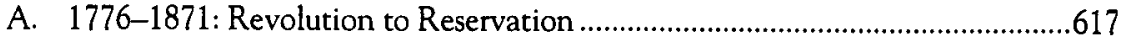

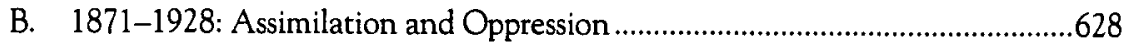

III. TWENTIETH CENTURY INNOVATIONS …..............................................................639

A. A Brief New Deal-A New Twist on the Old One: 1928-1968 ....................640

B. Equality and Backlash: 1968 to the Present......................................................646

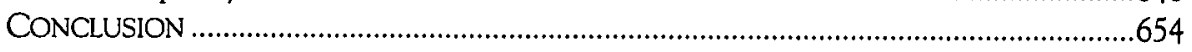

\section{INTRODUCTION}

What is the role of race, and particularly of racism, in American Indian law and policy? This question is particularly pressing today, as national attention focuses on the efforts of the Cherokee to limit their membership to those with Cherokee or Delaware blood, 'the U.S. Supreme Court continues to reduce tribal jurisdiction over non-Indians, ${ }^{2}$ and the recent Bush Administration has blocked recognition of Native Hawaiian sovereignty on the grounds that it is impermissibly race based. ${ }^{3}$ Although the federal government has wide constitutional discretion to implement its obligations to native people, ${ }^{4}$ in these and other places, questions of race continue to haunt Indian policy.

These questions become more difficult to answer because of the American tendency to measure racism according to its particular manifestations with respect to African Americans: slavery, control of labor, and the social segregation and classification of individuals according to descent. ${ }^{5}$ Although this paradigm obscures even the realities of black-white racism, it is particularly inadequate with respect to Indian-white relations, which since colonial days have not focused on the control of Indian labor, and have, at their most coercive, announced a goal of Indian assimilation. This paradigm also creates unease

1. S.E. Ruckman, Cherokee Freedmen: Tribe Reinstates Citizenship Unil Appeals Finished, TULSA WORLD, May 15, 2007, at A13.

2. See Plains Commerce Bank v. Long Family Land \& Cattle Co., 128 S. Ct. 2709 (2008) (holding that a tribal court lacked jurisdiction over a discrimination claim brought by a tribal member corporation against a non-Indian bank).

3. OFFICE OF MGMT. \& BUDGET, EXECUTIVE OFFCE OF THE PRESIDENT, STATEMENT OF ADMINISTRATION POLICY: H.R. 505, NATIVE HAWAIIAN GOVERNMENT REORGANIZATION ACT OF 2007 (2007) [hereinafter H.R. 505 POLICY STATEMENT].

4. See Morton v. Mancari, 417 U.S. 535 (1974) (holding that federal measures classifying Indians would be upheld so long as they were tied rationally to the federal government's unique obligations to Indian people).

5. See Adrienne D. Davis, Identity Notes Part One: Playing in the Light, 45 AM. U. L. REV. 695, 703-04 (1996); Juan F. Perea, The Black/White Binary Paradigm of Race: The "Normal Science" of American Racial Thought, 85 CAL. L. REV. 1213, 1248 (1997). 
with federal Indian law and policy, which to a great extent focus on the rights of tribes whose membership depends in part on descent.

This Article posits a new understanding of the way racism works in Indian law and policy. ${ }^{6} \mathrm{I}$ argue that although racism has been a persistent factor in Indian policy since very early in European American-American Indian relations, it has generally worked in very different ways than it does for African Americans. These differences do not mean that this is a story of de-racing. Unlike Latin Americans, who shifted from nonwhite to white and back again in U.S. law, or Southern European immigrants, who shifted from nonwhite to white, ${ }^{7}$ Indian people have been consistently regarded as a separate race since the $1700 \mathrm{~s}$ - the red in the North American box of colors. Because the meanings of race derive from the material, social, and ideological circumstances that generate them, ${ }^{8}$ however, the distinctive circumstances of Indian-white relations gave rise to very different notions and uses of Indian difference.

European Americans were not primarily concerned with using Indian people as a source of labor, and so did not have to theorize Indians as inferior individuals to justify the unfair terms of that labor. Rather, colonists' primary concern with respect to Indians was to obtain tribal resources and use tribes as a flattering foil for American society and culture. It was therefore necessary to theorize tribal societies as fatally and racially inferior while emphasizing the ability of Indian individuals to leave their societies and join non-Indian ones.' Throughout the most oppressive periods of Indian policy (and at the

6. The Article focuses less on race, the simple classification of people based on real or imagined differences in ancestry or appearance, see IAN F. HANEY-LOPEZ, WHITE BY LAW: THE LEGAL CONSTRUCTION OF RACE 14 (Richard Delgado \& Jean Stefancic eds., N.Y. Univ. Press 1996) [hereinafter HANEY-LÓPEZ, WHITE BY LAW], than on racism, the phenomena by which the assigned race comes to signify innate, natural, or permanent differences between individuals and groups. These differences are in turn used to justify advantage or privilege. See ALBERT MEMMI, RACISM 100 (Steve Martinot trans., Univ. of Minn. Press 2000) (1982). The focus on racism rather than race makes it easier to incorporate the ways culture, nationality, and religion have all been linked to privileges attached to notions of innate or biological differences. It also avoids the difficulties of policies that focus on eradication of race-conscious laws to the detriment of efforts to eradicate racist structures of privilege and power. See, e.g., Charles R. Lawrence III, The Id, the Ego and Equal Protection: Reckoning With Unconscious Racism, 39 STAN. L. REV. 317, 321 (1987).

7. See DAVID R. ROEDIGER, WORKING TOWARD WHITENESS: HOW AMERICA'S IMMIGRANTS BECAME WHITE (Basic Books 2005); Ian F. Haney-López, Race, Ethnicity, Erasure: The Salience of Race to LatCrit Theory, 85 CAL. L. REV. 1143, 1148 (1997).

8. See HANEY-LOPEZ, WHITE BY LAW, supra note 6, at 14-15; MiChael OMI \& HOWARD WINANT, RACIAL FORMATION IN THE UNITED STATES FROM THE 1960s TO THE $1990 \mathrm{~S} 61$ (Routledge 1994) (1986).

9. The late Vine Deloria noted this difference in the social meaning of race for American Indians as early as 1969, writing that while whites defined both blacks and Indians as animals, blacks were "draft animals" and Indians were "wild animals." VINE DELORIA, JR., CUSTER DIED FOR YOUR 
height of violent segregation of African Americans), policymakers continued to emphasize the need to encourage Indians to leave their tribes and assimilate with white society. At the same time, Indian tribes, regardless of their degree of actual conformity to non-Indian ideals, as well as Indians who followed the supposedly inborn urge to cling to tribal ways, were viewed as being fixed in the backward patterns of blood and habit, and doomed to disappear or to be destroyed. ${ }^{10}$

There are of course situations in which discrimination against American Indians accords with classical paradigms of racism. Indians have been denied the right to vote, ${ }^{11}$ attend schools with or marry whites, ${ }^{12}$ eat at restaurants, ${ }^{13}$ stay at hotels, ${ }^{14}$ or get jobs ${ }^{15}$ because of their race. Like African Americans, native people have been lynched, raped, ${ }^{16}$ and had their homes burnt out from under them ${ }^{17}$ because of their race. In some parts of the country, Indian people are "timber niggers" ${ }^{18}$ or "prairie niggas," ${ }^{19}$ the necessarily inferior economic and

SINS: AN INDIAN MANIFESTO 171 (Univ. of Okla. Press 1988) (1970). As a result, laws "systematically excluded blacks from all programs, policies, social events, and economic schemes," while Indians were "subjected to the most intense pressure to become white... The antelope had to become a white man." Id. at 172 .

10. See infra Part Il.B.

11. See, e.g., O.K. Armstrong, Set the American Indians Free!, READER's DIGEST, July 1945, at 47, 49 (recounting an example of a North Carolina election registrar charged with administering the literacy qualification telling a Cherokee man with a master's degree, "You couldn't read or write to my satisfaction if you stayed here all day").

12. See, e.g., State v. Duffy, 7 Nev. 342 (1872) (invalidating a 1867 law providing that "Negroes, Mongolians and Indians shall not be admitted into the public schools, but the board of trustees may establish a separate school for their education"); King v. Gallagher, 93 N.Y. 438 (1883) (discussing a New York law mandating the segregation of Indian children); PAULI MURRAY, STATES' LAWS ON RACE AND COLOR 53, 237 (Pauli Murray ed., The Univ. of Ga. Press 1997) (1951) (reprinting California and Mississippi laws on the segregation of Indians); id. at 18 (noting that by 1950, marriage between Indians and whites were barred in five states); GILBERT THOMAS STEPHENSON, RACE DISTINCTIONS IN AMERICAN LAW 81-83 (1910) (reporting that as of 1910, marriage between Indians and whites was barred in eight states, although black-white marriages were barred in twenty-six states).

13. PRESIDENT'S COMM. ON CIVIL RIGHTS, TO SECURE THESE RIGHTS: THE REPORT OF THE PRESIDENT'S COMMITTEE ON CIVIL RIGHTS 78-79 (1947) [hereinafter TO SECURE THESE RIGHTS].

14. Id.

15. Id. at 55 .

16. See Sarah Deer, Sovereignty of the Soul: Exploring the Intersection of Rape Law Reform and Federal Indian Law, 38 SUFFOLK U. L. REV. 455, 456-58 (2005) (discussing the high rate of interracial rape of native women as part of the 500-year history of sexual exploitation).

17. See Wenona T. Singel \& Matthew L.M. Fletcher, Power, Authority, and Tribal Property, 41 TULSA L. REV. 21, 26-27 (2005) (describing the burning out of the Odawa and Ojibwa town of Cheboygan).

18. See Lac du Flambeau Band of Lake Superior Chippewa Indians v. Stop Treaty Abuse Wis., Inc., 843 F. Supp. 1284, 1288 (W.D. Wis. 1994).

19. BRIDGES Student Org., Univ. of N.D. (March 2001), http://www.und.nodak.edu/org/bridges/images/poster2.jpg. 
social group. ${ }^{20}$ Throughout the United States, moreover, Native Americans fall at the bottom of assessments of education, health status, and income, and at the top of assessments of crime victimization and incarceration. ${ }^{21}$ But if one identifies racism only by the appearance of such paradigmatic manifestations, one would elide some of the most important ways that notions of Indian inferiority have been constructed and used.

One moment in time is illustrative. The end of the nineteenth century and beginning of the twentieth were one of the most coercive and racist periods in Indian law. This was the era of Wounded Knee, in which the Seventh Cavalry shot down scores of unarmed Lakota women and children. ${ }^{22}$ It was the era of allotment, in which the federal government declared two-thirds of Indian lands surplus and divided the rest among individual households to force them to farm and to overcome what was seen as their distaste for hard labor. ${ }^{23}$ It was also the period of the Indian boarding schools, which separated children from their parents for years in order to "kill the Indian ... to save the man." ${ }^{24}$ In case there was any doubt that notions of Indian race played a role in these policies, Theodore Roosevelt, who would soon become president, wrote triumphantly of the process through which the continent had "pass[ed] out of the hands of [its] aboriginal owners, and become the heritage of the dominant world races." ${ }^{25}$

But other aspects of the treatment of Indians during this period could result in the opposite conclusion, that Indian people were not the victims of racism at all. In the same period that sexual contact between blacks and whites was the surest way to raise a lynch mob to fury, intermarriage between Indians and whites was advocated by prominent policy makers and even rewarded by

20. See, e.g., TO SECURE THESE RIGHTS, supra note 13, 78-79 (noting that Indians faced the greatest difficulty accessing eating establishments and hotel accommodations in areas surrounding reservations); see also THOMAS BIOLSI, DEADLIEST ENEMIES: LAW AND THE MAKING OF RACE RELATIONS ON AND OFF ROSEBUD RESERVATION 2 (2001) (discussing racial antagonism between Indians and whites in South Dakota); Kevin K. Washburn, American Indians, Crime, and the Law, $104 \mathrm{MICH}$. L. REV. 709, 764 (2006) ("Racism and bias remain strong, particularly in states where Indians compete with non-Indians for limited resources.").

21. U.S. COMM'N ON CIVIL RIGHTS, A QUIET CRISIS: FEDERAL FUNDING AND UNMET NEEDS IN INDIAN COUNTRY 8, 34-35, 42, 67-69, 83-84 (2003); COHEN'S HANDBOOK OF FEDERAL INDIAN LAW 730, 1358, 1378-79 (Neil Jessup Newton ed., 2005) [hereinafter 2005 COHEN].

22. See Indians Tell Their Story; A Pachetic Recital of the Killing of Women and Children, N.Y. TIMES, Feb. 12, 1891, at 6.

23. See Judith V. Royster, The Legacy of Allotment, 27 ARIZ. ST. L.J. 1, 8 (1995).

24. AMERICANIZING THE AMERICAN INDIANS: WRITINGS BY THE "FRIENDS OF THE INDIAN" 1880-1900, at 261 (Francis Paul Prucha ed., Harvard Univ. Press 1973) [hereinafter AMERICANIZING THE AMERICAN INDIANS].

25. 3 THEODORE ROOSEVELT, THE WINNING OF THE WEST $45-46$ (Univ. of Neb. Press 1995) (1894). 
Congress under certain circumstances. ${ }^{26}$ And while the segregationist Jim Crow era closed its iron grip around African Americans, graduates of federal Indian boarding schools received university scholarships, Indian artists ran movie studios and starred in operas at Carnegie Hall, and Indian ballplayers played on both teams in the 1911 World Series. ${ }^{27}$ Throughout this period, moreover, much of the starkest oppression suffered by Indian people was publicly justified by the supposed need to integrate them. ${ }^{28}$

Despite the recent flourishing of scholarship on race and American Indians, ${ }^{29}$ the discrepancies between our classical understanding of racism and treatment of American Indians have not been examined thoroughly. The most visible scholarship, in particular that of Ward Churchill, focuses on the tools of racism familiar from black-white relations, such as attention to quantum of Indian blood, but fails to acknowledge the different meanings of blood quantum in black-white and Indian-white contexts. ${ }^{30}$ Robert Williams, the foremost legal scholar on Indian race, identifies the ways that assumptions of Indian inferiority help to shape federal Indian law, ${ }^{31}$ but anachronistically identifies racist assumptions in early Middle Ages preracial thought, ${ }^{32}$ and does not tie his insights to treatment of other racialized groups in the United

26. See infra Part II.B.

27. See id.

28. See id.

29. See, e.g., PHILIP J. DELORIA, INDIANS IN UNEXPECTED PLACES 85 (2004) Thereinafter Deloria, UneXPeCted Places]; PHILIP J. Deloria, Playnng Indian (1998) Thereinafter DeloRIA, Playing INDIAN]; JOANE NAGEL, AMERICAN INDIAN ETHNic RENEWAL: Red POWER AND THE ResurgenCE OF IDENTITY AND CULture (Oxford Univ. Press 1997) (1996); THEDA PERdue, "MiXed BlOOD" INDIANS: RACIAL CONSTRUCTION IN THE EARLY SOUTH (2003); CIRCE STURM, BLOOD POLITICS: RACE, CUlTURE AND IDENTITY IN THE CHEROKEE NATION OF OKLAHOMA (2002); Gavin Clarkson, Tribal Bonds: Statutory Shackles and Regulatory Restraints on Tribal Economic Development, 85 N.C. L. REV. 1009 (2007); Renee Ann Cramer, The Common Sense of Anti-Indian Racism: Reactions to Mashantucket Pequot Success in Gaming and Acknowledgment, 31 LAW \& SOC. INQUIRY 313 (2006); Rebecca Tsosie, The New Challenge to Native Identity: An Essay on "Indigeneity" and "Whiteness," 18 WASH. U. J.L. \& POL'Y 55 (2005); Gloria Valencia-Weber, Racial Equality: Old and New Strains and American Indians, 80 NOTRE DAME L. REV. 333 (2004).

30. See WARD CHURChILl, StRuggle FOR THE LAND: NATIVE NORTH AMERICAN RESISTANCE TO GENOCIDE, ECOCIDE AND COLONIZATION 380 (2002) (although native peoples were devoid of racism, "Euroamerican settlers ... foisted off the notion that Indian identity should be determined primarily by 'blood quantum,' an outright eugenics code similar to those developed in places like nazi Germany and apartheid South Africa"). For a more nuanced and accurate description of the uses of blood quantum, see Paul Spruhan, A Legal History of Blood Quantum in Federal Indian Law to 1935, 51 S.D. L. REV. 1 (2006).

31. See generally ROBERT A. WILLIAMS, JR., LIKE A LOADED WEAPON: THE REHNQUIST COURT, INDIAN RIGHTS, AND THE LEGAL HISTORY OF RACISM IN AMERICA (2005) [hereinafter WILLIAMS, LIKE A LOADED WEAPON]; ROBERT A. WILLIAMS, JR., THE AMERICAN INDIAN IN WESTERN LEGAL THOUGHT: THE DISCOURSES OF CONQUEST (1990) [hereinafter WILLIAMS, WESTERN LEGAL THOUGHT].

32. WILLIAMS, WESTERN LEGAL THOUGHT, supra note 31 , at 35. 
States. Sometimes efforts to make racism toward Indians look like racism toward African Americans reach ludicrous proportions. Deborah Rosen's 2007 book on American Indians and state law, the first to try to systematically catalog state laws classifying Indians, declares that "most states proscribed intermarriage between Whites and Indians, as they prohibited Whites and Blacks to intermarry," one page before she notes that only a handful of states prohibited Indian-white marriage in the nineteenth century compared to the majority that prohibited black-white marriage. ${ }^{33}$

Historians who do acknowledge the discrepancies between treatment of Indians and paradigmatic understandings of race often classify such divergences as the result of a period before racism toward Indians, and identify some moment-typically one with significance for black-white racism-at which Indian policy became, and remained, racist. Thus, Alden T. Vaughan, an expert in colonial Indian history, claims that racism began in the 1700 s when Indians were assigned the skin color red, and subsequently continued full force. ${ }^{34}$ William McLoughlin, in his otherwise brilliant histories of the Cherokee Nation, suggests that the Cherokee removal crisis of the 1820 s and early 1830 s reflects a new moment in which Indian policy was infected by scientific racism. ${ }^{35}$ Reginald Horsman also attributes a new racist turn regarding Indians to scientific racism, but places this moment over a decade later, in the 1840 s origins of the Reservation Era, in which tribes were confined on reservations to be groomed for civilization under the control of federal Indian agents. ${ }^{36}$ Just as racist oppression of African Americans began before each of these moments, so did racist justifications for oppression of native governments. More important, the anomalies in the form and rationale for oppression of American Indians existed after each moment these accomplished scholars designate as the inception of racism.

This Article covers a broader historical swath to illustrate the distinctive ways that notions of Indian racial inferiority developed and were used. This

33. DEBORAH A. ROSEN, AMERICAN INDIANS AND STATE LAW: SOVEREIGNTY, RACE, AND CITIZENSHIP, 1790-1880, at 110-11 (2007). Even the identification of nine states out of thirty-eight that did prohibit intermarriage, see id., depends on including states that prohibited intermarriage only very briefly, such as Tennessee, which enacted the prohibition in 1821 (by adopting a North Carolina law) but repealed the prohibition the following year. See DAVID FOWLER, NORTHERN ATTTTUDES TOWARDS INTERRACIAL MARRIAGE: LEGISLATION AND PUBLIC OPINION IN THE MIDDLE ATLANTIC AND THE STATES OF THE OLD NORTHWEST, 1780-1930, at 422 (1987).

34. See ALDEN T. VAUGHAN, THE ROOTS OF AMERICAN RACISM: ESSAYS ON THE COLONIAL EXPERIENCE 5 (1995).

35. William G. MCloughlin, Cherokee Renascence in THe New Republic, at $\mathrm{xv}-\mathrm{xvi}(1986)$.

36. Reginald Horsman, Scientific Racism and the American Indian in the Mid-Nineteenth Century, 27 AM. Q. 152, 166-68 (1975). 
history shifts back and forth between law, culture, and politics, showing how each shapes and is shaped by the others. I cannot hope to explain the manifestations of racism at all times with respect to all American Indian groups. Experiences of racism shift widely across tribes and eras of interaction; ${ }^{37}$ this Article can only identify patterns, leaving the rich divergences for future scholarship. Although the particular manifestations of racism vary across different periods, patterns emerge across the eras as tribes are reinscribed as inferior, limited, and defined by their race to justify limiting tribal independence and controlling Indian people. Identification of these patterns allows us to see the ways that they reappear to the present day in policy debates, in popular protests, and in the Supreme Court.

The Article often draws comparisons with the treatment of African Americans, and to a lesser extent other racialized groups, showing both the contrasts and links between these processes of racialization. Although I do not argue that racist treatment of American Indians and African Americans proceeded along parallel tracks, there are odd confluences in these eras. The Allotment and Assimilation Period of the 1870s to 1920s, for example, when two-thirds of tribal lands were divided among non-Indians, and Indian children were placed in federal boarding schools designed to destroy tribal culture and language, was also the height of Jim Crow and racist violence against African Americans. ${ }^{38}$ Moving to the 1950 s and 1960s, Senator Sam Ervin, the "rational" Southern voice against integration, was also the primary advocate of Termination Era legislation seeking to bring civil rights to the Indians by imposing governmental control on them. ${ }^{39}$ Equally striking, in the same term in 1978, the Supreme Court decided both Regents of the University of

37. Indian groups designated as "mulattoes," like the Lumbee of North Carolina or the "Moors" of Delaware, experienced far more segregation than others. See MURRAY, supra note 12, at 71,330 (reprinting a Delaware law providing separate schools for the "children of people called Moors or Indians," and a North Carolina law providing that "no child with negro blood, or what is generally known as Croatan Indian blood, in his veins, shall attend a school for the white race, and no such child shall be considered a white child"). Interestingly, California, whose Indian relations were forged from the brutality of the gold rush, the Spanish history of indentured servitude, and the failure to ratify any of the numerous treaties made with its tribes, placed racial restrictions on Indian integration that mirrored those placed on African Americans. See Lee v. Giraudo (In re Monks' Estate), 120 P.2d 167, 172 (Cal. 1941) (quoting a law prohibiting black-white intermarriage); People v. Washington, 36 Cal. 658, 666 (1869) (invalidating a law barring Indian, Mongolian, or Chinese testimony against whites); MURRAY, supra note 12, at 53 (reprinting a California law providing that Indian children may not attend white schools).

38. See infra Part II.B.

39. See text accompanying infra notes 325-335. During the Termination Era, the federal government sought to end the special status of Indian tribes, ending the federal relationship with a number of tribes, and placing many more under state jurisdiction. 
California ข. Bakke, ${ }^{40}$ which laid the groundwork for limits on the ability of the law to create true equality for African Americans, ${ }^{41}$ and Oliphant v. Suquamish Indian Tribe, ${ }^{42}$ which undermined efforts to create equality for Indian governments by denying them jurisdiction over non-Indians. ${ }^{43}$ Both decisions were products of a backlash against efforts to achieve equality that unduly threatened members of the dominant race. Through history, apparently inconsistent treatment of African Americans and American Indians are revealed as products of the same era and attitudes toward race.

A few clarifications are in order. Most important, this Article should not be understood to argue that tribes are at heart racial groups. The reverse is true: I argue that the basic racist move at work in Indian law and policy is to racialize the tribe, defining tribes as racial groups in order to deny tribes the rights of governments. Second, this Article does not argue that racism defines all of Indian law and policy. Perhaps even more than for other racial groups, important currents in Indian law and policy have supported a notion of tribal equality and self-government. ${ }^{44}$ Moreover, as any theory arguing that material interests importantly contribute to racial oppression must acknowledge, many interests and impulses other than racism affected Indian policy. ${ }^{45}$ Finally, this Article does not attempt to establish some kind of equivalency of oppression between Indians and African Americans or the many other victims of racism in the United States. ${ }^{46}$ Not only is there enough heartache for all to share, but a premise of this Article is that we have obscured a complete understanding of the way race works in America by trying to measure it against the experience of a single group. ${ }^{47}$

With those caveats, the Article proceeds in three parts. First, Part I briefly sketches the development of the idea of race in the modern era, emerging from antecedent classifications by religion and nation, and then shows how these

40. 438 U.S. 265 (1978).

41. Id. (plurality opinion) (invalidating an affirmative action plan reserving medical school slots for minority candidates).

42. 435 U.S. 191 (1978).

43. See text accompanying infra notes 364-370.

44. This Article differs, therefore, from the positions of Robert A. Williams and others who see federal Indian law as solely informed by racism and notions of Indian inferiority. See, e.g., WILLIAMS, LIKE A LOADED WEAPON, supra note 31.

45. See, e.g., 2005 COHEN, supra note 21 , at 16 (describing the way that the need to trade with Indians and to avoid warfare influenced Indian land policy).

46. See generally Devon W. Carbado, Race to the Bottom, 49 UCLA L REv. 1283 (2002) (discussing the difficulties with the effort to posit a bottom of comparative hardship in race scholarship).

47. Understanding racism against one group, however, does illuminate the roots of racism against others. See Mari Matsuda, Planet Asian America, 8 ASIAN L.J. 169, 170-71 (2001) (arguing that the practice and ideology of racism toward African Americans shaped treatment that Asians experienced upon arriving in America). 
differences became understood as racial differences written on the bodies of Indians and African Americans during the colonial period. Indian peoples shifted from potentially equal governments burdened solely by lack of religion and civilization to barbarous natives whose differences were rooted in nature. Although enslavement of Indians was ubiquitous during much of the colonial period, it faded from significance in the colonies by the late 1700 s as African Americans became racially fixed in this role and American Indians fixed in their role of absorption and disappearance.

Part II moves to the period between the Founding and the early twentieth century, as ever greater oppression and denigration of Indian governments combined with continued insistence on the need to assimilate the Indian people. Although the increasing restrictions on free people of color did impact native people during this period, laws mandating such segregation were the exception rather than the rule. The products of popular culture-the movies and dime novels-similarly demonized the tribe while presenting a stereotyped but often sympathetic view of Indian attempts to assimilate. Part III concerns the policy shifts of the twentieth century, in which new efforts to secure tribal equality have been met by renewed assertions of the inherent inferiority of tribal governments, joined this time by efforts to destroy tribal sovereignty in the name of racial freedom and equality. In conclusion, I discuss the implications of this history for current debates regarding race and American Indians, including the impact of Equal Protection law on measures protecting tribal sovereignty, and the current exclusion of freedmen citizens from the Cherokee and Seminole Tribes.

This Article thus moves from the first colonization of the United States to some of the most debated pending issues in Indian law. It sheds light not only on contemporary debates in the U.S. Congress and the Supreme Court, but also on the origins of American identity and the persistent uses of race in modern society. In so doing, it hopefully contributes to the continuing struggle for Indian survival.

\section{COMMON ORIGINS, Divergent PATHS: COLONIAL USES OF AFRICAN AND INDIAN RACE}

The racialization of African Americans and American Indians emerged from common origins, but, at least in North America, took divergent paths. Both grew from a combination of elements of the late middle ages and the early modern era: the growth of religious persecution, the birth of national identity, the expansion of maritime exploration, and, more surprisingly, the emergence of democracy and the age of enlightenment. English colonial notions of Africans 
and Indians were the products of these phenomena, but took unique shapes in response to the distinctive needs with respect to these groups. ${ }^{48}$ Although Europeans initially interacted with Indian tribes as relatively equal political entities, over the course of the period they were increasingly perceived as permanently inferior, facilitating denial of their political and property rights. At the same time, African Americans were posited as individually marked, justifying their enslavement and leading to laws preventing their interactions with whites on terms of equality. Although American Indians were also widely enslaved and similarly legally restricted as individuals for much of the period, de jure slavery ended in most colonies in the mid-eighteenth century and with it many of the restrictions intended to deny individual Indian equality. While racial discrimination against individual Indians remained, by the dawn of the new nation the emphasis on Indian assimilation would mean that such discrimination had to be justified in the name of Indians' continuing ties to their tribes.

\section{A. Origins of Racial Domination}

Neither oppression of Africans nor of Indians was, at least originally, the product of racism itself. A variety of accounts agree that racism is a product of the modern era, beginning to appear around the 1400 s, and not reaching full form until much later. ${ }^{49}$ But the seeds of racism were laid by antecedent forms of discrimination, especially religious oppression, combined with the development of nationalism, advancements in science and technology, and

48. Cf. Cheryl I. Harris, Whiteness as Property, 106 HARV. L. ReV. 1709, 1715 (1993) ("Although the systems of oppression of Blacks and Native Americans differed in form-the former involving the seizure and appropriation of labor, the latter entailing the seizure and appropriation of land-undergirding both was a racialized conception of property implemented by force and ratified by law.").

49. See ROBIN BLACKBURN, THE MAKING OF NEW WORLD SLAVERY: FROM THE BaROQUE TO THE MODERN 1492-1800, at 13-15 (1997); IVAN HANNAFORD, RACE: THE HISTORY OF AN IDEA IN THE WEST 5-6 (1996); OMI \& WINANT, supra note 8, at 61-63. In the ancient world, for example, "ethnos" signified those governed by passion rather than law; the acceptance of a government of law, regardless of what we today know as ethnicity, made the former "ethnos" into "politikos." See HANNAFORD, supra, at 21-22. In ancient Greece and Rome, the dark-skinned Ethiopians were described with admiration and respect, while the blue-eyed Scythians were considered among the lowest peoples. Id. at 26. Even in the Middle Ages, Noah's curse condemning the descendants of his son Ham to servitude was not associated with Africa or dark skin; the descendants of Ham were often described as settling in Europe or Asia, and the curse of perpetual servitude was more frequently invoked to justify oppression and control of the poor. Benjamin Braude, The Sons of Noah and the Construction of Ethnic and Geographical Identities in the Medieval and Early Modem Periods, 54 WM. \& MARY Q. 103, 113, 116, 120-22, 133 (1997). 
emergent notions of democracy, equality, and consumerism. The combination of these factors had important consequences for Africans and Indians.

One of the most significant early forms of discrimination was religious oppression. In the late Middle Ages and early modern era, Christian governments not only used divergent religious belief as an excuse for oppression and usurpation, but also began to see different religious origins as a stain on the blood of the adherent that could not be cleansed by simple conversion. Papal decrees used failure to follow the Christian god as a legal justification for the Crusades. ${ }^{50}$ Within Europe, Jews and Muslims were segregated, expelled, and even murdered in religious hysteria. ${ }^{51}$ Soon, fear of false converts and disguised infidels began to shift to the bodily finality of race, leading to requirements of special dress to mark the Jew, as well as different treatment of the conversos (converts) from those certified as being of limpio de sangre (pure blood). ${ }^{52}$

The second important ideological and political innovation was the development of the nation-state. In the early modern era, the universal European empire began to be replaced by distinct, territorially defined nations, whose members' first allegiance was to a common government, and who communicated through a common and distinct language. Along with the idea of distinct nations came that of a distinct national character inherent in the air, the soil, and the blood of the nation and its citizens. ${ }^{53}$ Just as important as ideological emphasis on a national character was a new material development: the race to achieve national economic superiority by dominating newly discovered continents and their resources. ${ }^{54}$

Scientific and technological developments aided in the transformation of these factors into racism. Early Enlightenment biologists like Carlus Linnaeus began to classify the members of the animal and plant kingdoms. ${ }^{55}$ Their methods allowed later racists to depart from the biblically derived belief in a common human origin to posit innately inferior races. ${ }^{56}$ At the same time, advances in shipbuilding and navigation techniques brought Europeans into contact with new continents and peoples who wore their national and religious differences on their faces. ${ }^{57}$

50. WILLIAMS, WESTERN LEGAL THOUGHT, supta note 31 , at 35-50.

51. HANNAFORD, supra note 49 , at 116-20.

52. Id. at 119-22.

53. See BLACKBURN, supta note 49, at 4; HANNAFORD, supra note 49, at 188-90.

54. BLACKBURN, supra note 49 , at 17 .

55. HANNAFORD, supta note 49, at 63, 204; WINTHROP D. JORDAN, WHITE OVER BLACK: AMERICAN ATTITUDES TOW ARD THE NEGRO, 1550-1812, at xii (W.W. Norton \& Co. 1977) (1968); OMI \& WINANT, supra note 8, at 63.

56. JORDAN, supra note 55 , at xii-xiii.

57. See BLACKBURN, supra note 49, at 13-15. 
Emergent notions of democracy, equality, and consumerism were a deadly addition to this mix. Although serfdom and slavery of fellow citizens and coreligionists had been commonplace in the Middle Ages, ideological competition with Islam, which prohibited the enslavement of fellow Muslims, led Christian countries to shun these practices. ${ }^{58}$ Slavery became even more difficult to justify in the face of nationalist claims of the shared superiority of nations and their people, especially for the English (and later Americans) who held liberty and consent to be their particular national genius. ${ }^{59}$ As the lower classes became ideologically protected from involuntary labor, however, racially marked peoples appeared to fill their place. Less directly, the insatiable demands for African labor and Indian lands were the product of an economy that was moving from subsistence to plantation-grown luxury goods such as tobacco, indigo, and sugar that were no longer reserved to the upper classes but demanded by the developing middle class. ${ }^{60}$ We see all of these elements in the transformation of Africans into a permanently inferior labor force and Indians into a permanently inferior nation.

\section{B. Evolution of Racism in the New World}

The first enslavement of Africans and conquest of Indian lands were justified not by race, but by religion and national difference. The Canary Islands, in which Portugal began its European dominance of the international slave trade, were populated by the phenotypically white Guanches. ${ }^{61}$ King Duarte of Portugal, however, was able to obtain papal sanction for their conquest by describing them in terms later used to justify oppression of Africans and Indians: "wild men who inhabit the forests," "not united by a common religion," and "living in the country like animals. ${ }^{.62}$ Two decades later, Pope Nicholas V authorized enslavement of the peoples of Africa and conquest of its nations, but in explicitly religious, not racial, terms, sanctioning Portugal "to invade, search out, capture, vanquish, and subdue all Saracens and pagans

58. Id. at 38-39.

59. EDMUND S. MORGAN, AMERICAN SLAVERY, AMERICAN FREEDOM: THE ORDEAL OF COLONIAL VIRGINIA 386-87 (W.W. Norton \& Co. 2003) (1975); $c f$. JORDAN, supra note 55, at 49 (placing the emergence of "preening consciousness of the peculiar glories of English liberties" in the 1550s).

60. See BLACKBURN, supra note 49, at 17.

61. See Alice Carter Cook, The Aborigines of the Canary Islands, 2 AM. ANTHROPOLOGIST $451,456,458$ (1900) (reporting accounts of Guanches as "blond" or "swarthy" and "white").

62. BLACKBURN, supra note 49 , at 62 . 
whatsoever, and other enemies of Christ wheresoever placed," to "reduce their persons to perpetual slavery, and to apply and appropriate [their] kingdoms." ${ }^{163}$

This use of religious difference was exported to justify Spain's domination of the Americas and their peoples. ${ }^{64}$ In the Spanish American mainland, Indians became the conscripted laborers, forced into the mines and the fields as slaves and encomenderos, the property of the Spanish conquistador who had been granted their land. ${ }^{65}$ As lack of Christianity alone could not justify permanent slave status, apologists for conscription argued that Indians were permanently inferior, too idle to support themselves without Spanish supervision and unable to understand economic value. ${ }^{66}$ Although Spanish laws prohibited chattel slavery of Indians by the mid-sixteenth century, ${ }^{67}$ Indians remained involuntary laborers, forced by the repartimiento to work for the Spanish for little or no pay a portion of each year. ${ }^{68}$ This distinctive history has resulted in important differences between the political and racial struggles of indigenous peoples of Latin America and the United States. ${ }^{69}$

English attempts to colonize North America did not take the same path. English overseas efforts were spurred by the desire to prove England's superiority to Spain. Stories of Spanish cruelty to the natives were popular national propaganda, justifying English desires to appropriate the lands for themselves. ${ }^{70}$ The first schemes to stake English claims to North American land were conceived of as a kind of tri-racial liberation movement, joining runaway African Cimarrons and oppressed Indians to fend off Spanish conquistadores. ${ }^{11}$

While these visions were short lived, the fiction of benefit to native peoples remained part of the Anglo-American nationalist myth. English colonization was justified because the English would bring the Indians true religion, would

63. BULL ROMANUS PONTIFEX (1455), reprinted in EUROPEAN TREATIES BEARING ON THE HISTORY OF THE UNITED STATES AND ITS DEPENDENCIES TO 1648, at 23 (Frances Gardiner Davenport ed., 1917) (hereinafter EUROPEAN TREATIES].

64. See THE BULL INTER CAETERA (1493), reprinted in EUROPEAN TREATIES, supra note 63, at 76 (granting Isabella and Ferdinand authority to "bring under your sway [the Americas] and islands with their residents and inhabitants and to bring them to the Catholic faith").

65. BLACKBURN, supra note 49, at 129, 133; LEWIS HANKE, THE SPANISH STRUGGLE FOR JUSTICE IN THE CONQUEST OF AMERICA 19-20 (1949).

66. HANKE, supra note 65 , at $43-44$.

67. BLACKBURN, supra note 49, at 134.

68. See id. at 144-46; see also id. at 143 (stating that African slaves were often employed as overseers of Indians and given more prestigious work).

69. See PATRICIA SEED, AMERICAN PENTIMENTO: THE INVENTION OF INDIANS AND THE PURSUIT OF RICHES 1-2 (2001) (noting that although the primary struggle of North American indigenous peoples is for land, the basis of national equality, the primary struggle of South American Indians is for dignity, the hallmark of individual equality).

70. MORGAN, supra note 59, at 6-8.

71. Id. at $12-14$. 
acquire land only by purchase, and would teach Indians how to use their land to ensure prosperity. The faith in the inferiority of the Indian community, the attractiveness of the English, and the malleability of the individual Indian were thus placed at the heart of the fledgling North American colonies. All three were challenged on arrival, but were replaced or reinforced with notions of the inherent inferiority of Indian tribes.

Although religious superiority was the earliest and the most fervent of the initial justifications for colonization, ${ }^{72}$ the religious mission of the early colonies also made it easy to see God's will in the acquisition of Indian bodies (through death) as well as souls. Governor John Winthrop's letters are the infamous example of this, referring to smallpox epidemics as the means by which "God hath[] ... cle[a]red our title to this place," and a sign that the Lord was "pleased with our inheriting these parts ... taking[ ] it from a people who had long usurped upon him, and abused his Creatures." ${ }^{73}$ A similar conflation of divine will and Indian death appears in the official declaration of a day of thanksgiving to commemorate success in King Philip's War, the 1675-1676 war with the tribes led by the Wampanoag sachem Metacom. The Massachusetts government lauded the will of "God that made bare his own arm for our deliverance," so that of the tribes that rose against them "there now scarce remains a name or family of them in their former habitations but are either slain, captivated, or fled into remote parts of this wilderness. ${ }^{174}$ The lesser value on human life characteristic of racism thus emerged naturally from emphasis on religious superiority.

War blended with convictions of religious inferiority to generate ideas of innate Indian difference. ${ }^{75}$ Although tribes and colonists were initially able to negotiate mutually beneficial alliances, ${ }^{76}$ English and Indian soon clashed on the terms of their coexistence. The resulting violence contributed to the

72. See, e.g., THE FIRST CHARTER OF VIRGINIA (1606), in 7 THE FEDERAL AND STATE CONSTITUTIONS, COLONIAL CHARTERS, AND OTHER ORGANIC LAWS OF THE STATES, TERRITORIES, AND COLONIES NOW OR HERETOFORE FORMING THE UNITED STATES OF AMERICA 3783 (Francis Newton ed., 1909); Instructions to the Resident Governor (Feb. 16, 1629), in 17 EARLY AMERLCAN INDIAN DOCUMENTS, TREATIES AND LAWS, 1607-1789, at 74 (Alden T. Vaughan \& Deborah A. Rosen eds., 2003) [hereinafter EARLY INDIAN DOCUMENTS] (declaring that "endeavoring[] to bring[ ] the Indians to the knowledge of the gospel[ ]" is the "main end of our plantation").

73. See Letter From John Winthrop to John Endecott (Jan. 3, 1634), in 3 WINTHROP PAPERS, 1631-1637, at 149 (Allyn Bailey Forbes ed., 1943); Letter From John Winthrop to Sir Simonds D'ewes (July 21, 1634), in 3 WINTHROP PAPERS, 1631-1637, supra, at 171-72.

74. Law to Order a Day of Humiliation (Oct. 25, 1676), 17 EARLY INDIAN DOCUMENTS, supra note 72 , at 136.

75. Cf. JILL LEPORE, THE NAME OF WAR: KING PHILIP'S WAR AND THE ORIGINS OF AMERICAN IDENTITY, at xiii (1998) (arguing that the 1675 war between the English and the Indians "drew new, firmer boundaries berween English and Indian people ... and between what it meant to be 'English' and what it meant to be 'Indian"').

76. See 2005 COHEN, supra note 21 , at 17. 
shift in perceptions of the Indian from misled Englishman to untrustworthy Other. These shifting perceptions went to the heart of what Indians were as human beings. One chronicler of the 1622 attack by the Tidewater Confederacy on Jamestown, for example, portrayed the attackers as subhuman and (in contravention of religious doctrine) not a product of the original Creation, but

Errors of nature, of inhumane Birth,

The very dregs, garbage, and spanne of Earth;

Who ne're (I think) were mention'd with those creatures

$A D A M$ gave names to in their several natures;

But such as coming of a later Brood,

(Not sav'd in th' Arke) but since the general Flood ... ."

War also shifted ideas of the value of Indian life, resulting in laws sanctioning and rewarding killing of any Indian, enemy or not, who did not accept colonial restrictions. In 1675, the Massachusetts Bay Council ordered all Indians to confine themselves to three established Indian praying towns; should any Indian be discovered outside these limits, it would be lawful for any person "to kill and destroy them as they best may or can." ${ }^{\text {"78 }}$ In 1689, the colony began offering rewards for scalps of any Indian found outside these limits, a practice soon followed by the other colonies. ${ }^{79}$ By 1755 , an enterprising "volunteer" could earn one hundred pounds for the scalp of a male Indian over twelve years of age, and fifty for that of a women or child..$^{50}$ Although efforts to convert the Indians continued along with these efforts to exterminate them, the laws reflect a new dichotomy: Separated from his tribe, the Indian could be civilized and would thereby add glory of the English race; tied to it, however, he was an enemy of all civilization.

In a testament to the way social meaning informs physicality, even the perception of Indian appearance changed. Early accounts of the Indians had emphasized their physical beauty, describing Indians as among the "goodliest $\mathrm{m}[\mathrm{e}] \mathrm{n}$ that ever we beheld." ${ }^{, 81}$ Initial drawings pictured Indians either as wholly inhuman monsters, with eyes in their bellies and no heads, or as humans constructed on a Greco-Roman scale, taller and nobler than the clothed

77. Christopher Brooke, A Poem on the Late Massacre in Virginia, With Particular Mention of Those Men of Note That Suffered in That Disaster, quoted in ROBERT F. BERKHOFER, JR., THE WHITE MAN'S INDIAN: IMAGES OF THE AMERICAN INDIAN FROM COLUMBUS TO THE PRESENT 20 (1979).

78. Law (United Colonies) to Wage War Against "Barbarous Natives", reprinted in 17 EARLY INDIAN DOCUMENTS, supra note 72, at 124.

79. Id. at 61 .

80. Law to Reward the Killing of St. Johns or Cape Sable Indians, reprinted in 17 EARLY INDIAN DOCUMENTS, supra note 72, at 192.

81. Karen Ordahl Kupperman, Presentment of Civility: English Reading of American Self-Presentation in the Early Years of Colonization, 54 WM. \& MARY Q. 193, 198 (1997). 
Europeans who encountered them. ${ }^{82}$ But in Mary Rowlandson's account of her captivity by the Indians during King Philip's War, we see something very different. Upon seeing a group of riders approaching from afar, Rowlandson wrote,

My heart skipt within me, thinking they had been Englishmen at their first sight of them, for they were dressed in English Apparel, with hats, white Neckcloths, and Sashes about their waists ... but when they came near, there was a vast difference between the lovely faces of Christians, and the foul looks of those heathens. ${ }^{83}$

Despite acquisition of the trappings of English culture, the Indians' nature is fundamentally marked on their faces. Rowlandson's narrative became the first bestseller of the New World. ${ }^{84}$

Perceptions of Indian agriculture and its meaning underwent a similar transformation, making its deficits a permanent Indian quality. England had staked its legal claims to North America in part on the argument that other European countries had not yet actually "planted" or cultivated those lands; similarly, the right to plant in New England rested on the notion that the native inhabitants had not actually cultivated and enclosed the land. ${ }^{86}$ But on reaching the New World, the colonists found that not only did the tribes they encountered farm their lands, ${ }^{8 i}$ but that the English were dependent on native harvests to survive. ${ }^{88}$

82. See DELORIA, PLAYING INDIAN, supra note 29 , at 20-21.

83. JAMES MULDOON, IDENTITY ON THE MEDIEVAL IRISH FRONTIER: DEGENERATE ENGLISHMEN, WILD IRISHMEN, MIDDLE NATIONS 63 (2003).

84. See June Namias, White Captives: Gender AND ETHNicity on the Western FRONTIER 9 (1993).

85. See SEED, supra note 69, at 16-17 (1995).

86. See EUROPEAN TREATIES, supra note 63, at 247 n.4, 248 (noting Winthrop's 1629 justification from England).

87. Indeed, much early colonial Indian legislation, and possibly one of the causes of the 1675 war with the Wampanoag, concerned the problem of English cattle trampling Indian corn fields. See Law to Improve Relations With Indians, reprinted in 15 EARLY INDIAN DOCUMENTS, supra note 72 , at 62-63; Law to Compensate Indians for Damage to Corn, reprinted in 17 EARLY INDIAN DOCUMENTS, supra note 72, at 20; Law to Create a Pound for Horses and Cattle, reprinted in 17 EARLY INDIAN DOCUMENTS, supra note 72, at 21; Law to Require Indians to Build Fences, reprinted in 17 EARLY INDIAN DOCUMENTS, supra note 72, at 23; Law to Compensate Indians for Damage to Corn, reprinted in 17 EARLY INDIAN DOCUMENTS, supra note 72, at 23; Laws Concerning Indians in the Code of 1660, reprinted in 17 EARLY INDIAN DOCUMENTS, supra note 72, at 112-13.

88. The very first records of the new Connecticut colony, for example, concerned punishment for a man who illegally traded a gun to the local Indians for com. See 1 THE PUBLIC RECORDS OF THE COLONY OF CONNECTICUT PRIOR TO THE UNION WITH NEW HAVEN COLONY 1 (J. Hammond Trumbull ed., AMS Press \& johnson Reprint Corp. 1968) (1850) [hereinafter COLONIAL RECORDS OF CONNECTICUT] (reprinting law of Feb. 9, 1637). The new settlements repeatedly curtailed the com trade, only to be forced to reopen it to satisfy the colonists' hunger. See id. at 11, 13, 17-18 (detailing the Connecticut restrictions as well as the lifting of these restrictions); Laws to Prevent 
Although these uncomfortable facts contributed to the insistence on purchase of Indian lands, the insistence that Indians were a people that did not farm had become a fundamental symbol of American Indian inferiority and Anglo American genius. Locke's image of "the wild Indian" who could not feed his community and had not established any property rights in America for "want of improving it by labor" became a convenient foil for the Anglo Saxon notion of property rights. ${ }^{89}$ In 1758 , Emmerich de Vattel built this perception into an explicit justification for North American colonization, arguing that although it was unjust to colonize Latin America, where the indigenous peoples had cultivated the soil, it was right to claim North America, where they had not. ${ }^{90}$ Although the colonists surely knew better, at least in the early years, soon the only Indian communities that remained in their midst were the impoverished praying Indians in the north and the tributary tribes in the south. ${ }^{91}$ By the late eighteenth century, the Anglo Americans were again reciting the lack of Indian agriculture as a justification for claiming their land. ${ }^{92}$

This is not to say that the colonists acquired significant land without at least the guise of contract. All of the colonies early enacted laws preventing the colonists from taking land from the Indians except by purchase, and within a short period each also prohibited acquisition of Indian land without approval by the local government. ${ }^{93}$ Colonies enacted a similar series of laws to forbid sales on credit to the Indians, denying recourse to the courts to any Englishman who violated the prohibition. ${ }^{94}$ All of these laws were at least partially protective, intended to prevent fraud and overreaching by Englishmen. ${ }^{95}$ But whatever the

Attack by Indians, reprinted in 15 EARLY INDIAN DOCUMENTS, supra note 72, at 19; Law to Curtail Purchases of Com, reprinted in 15 EARLY INDIAN DOCUMENTS, supra note 72, at 24; Law to Allow Trade for Corn, reprinted in 15 EARLY INDIAN DOCUMENTS, supra note 72, at 32 (documenting the Virginia restrictions and the lifting of these restrictions).

89. See JOHN LOCKE, TWO TREATISES OF GOVERNMENT, 286-87, 296-97 (Peter Laslett ed., Cambridge Univ. Press 1988) (1690). Stuart Banner has shown that Locke was familiar with Indian farming from his service as an administrator of the Carolina colony and later secretary to the British Board of Trade. STUART BANNER, HOW THE INDIANS LOST THEIR LAND 46-47 (2005) (suggesting that ideas of English identity were more important than Indian reality in such constructions of difference).

90. EMMERICH DE VATTEL, THE LAW OF NATIONS 103-04 (Joseph Chitty ed. \& trans., T. \& J.W. Johnson \& Co. 1867) (1758).

91. See BANNER, supra note 89, at 153.

92. Id.

93. 2005 COHEN, supra note 21 , at 17 .

94. Laws to Govern Indians, reprinted in 17 EARLY INDLAN DOCUMENTS, supra note 72, at 56, 59 (reprinting a 1685 Plymouth law); see COLONIAL RECORDS OF CONNECTICUT, supra note 88, at 95 (law of Oct. 12, 1643).

95. See, e.g., Law to Protect Indian Servants, reprinted in 17 EARLY INDIAN DOCUMENTS, supra note 72, at 165 (justifying a law prohibiting sales on credit by complaints of "some of the principal and best disposed Indians within this province have represented and complained of the exactions and oppression which some of the English exercise towands the Indians, by drawing them to consent 
motivation, the inability to sell their land or enter into contracts contributed to the transformation of Indian communities in the public mind into inferior groups that did not possess and could not exercise full legal rights.

The need to develop firm notions of English superiority was challenged in part by the attractiveness of Indian communities for the struggling settlers. Early colonial laws provided draconian punishment to settlers who left the colonies to join Indian communities. ${ }^{96}$ Indians who crossed in the other direction, however, helped to confirm English superiority. The notion of intermarriage as a means to strengthen the English cause was part of the propaganda for colonization. In Eastward Ho, a popular play produced in London in 1605, an organizer of the Virginia venture claims that the English left behind in the failed attempt to colonize Roanoke "have married with the Indians, and make 'em bring forth as beautiful faces as any we have in England: and therefore the Indians are so in love with 'em, that all the treasure they have they lay at their feet.".97

The effort to incorporate Indians became official policy. The early colonies were instructed to "get[] some [Indian] children" to bring up in Christianity and the English language. ${ }^{98}$ Pocahontas, herself first brought into contact with John Rolfe as a hostage when she was kidnapped during tense negotiations with her father Powhatan, ${ }^{99}$ became the poster child for the more intimate method of conversion. Rolfe was praised for his marriage to her, "one of rude education, manners barbarous and cursed generation, merely for the good and honor of the Plantation." ${ }^{100}$ The alliance was so successful that Deputy Governor Thomas Dale later sent an emissary to ask Powhatan for the hand of his youngest daughter, who was not yet twelve. ${ }^{101}$ As if to emphasize that the goal of such exchange of cultures was to strengthen only English society, a few years later the colony prohibited giving the Indians "any English dog of quality, as a

to, covenant or bind themselves or children apprentices or servants for an unreasonable term on pretence of, or to make satisfaction for some small debt contracted, or damage done by them").

96. See, e.g., Laws Divine, Morall, and Martiall, Etc., reprinted in 15 EARLY INDIAN DOCUMENTS, supra note 72, at 14, 15 (reprinting a 1612 law punishing with death those who ran away to Indians); COLONIAL RECORDS OF CONNECTICUT, supra note 88, at 78 (reprinting a 1642 law providing at least three years punishment, and additional fines or corporal punishment at the court's discretion, for those that left to settle with the Indians).

97. KAREN KUPPERMAN, THE JAMESTOWN PROJECT 99-100 (2007).

98. Instructions to the Resident Governor, reprinted in 17 EARLY INDIAN DOCUMENTS, supra note 72, at 74 (reprinting Massachusetts 1629 instructions); see also Law to Promote Conversion of Indians to Christianity, reprinted in 15 EARLY INDIAN DOCUMENTS, supra note 72, at 16 (reprinting a Virginia 1619 law).

99. RAlPH Hamor, A TRUe Discourse of THE PRESENT State OF Virginia (Va. State Library Publ'ns 1957) (1615).

100. Id. at 24 .

101. Id. at 37, 40-42. Powhatan refused, calling it "not a brotherly part of your King, to desire to bereave me of two of my children at once." Id. at 42. 
Mastive, Greyhound, Blood hound[ ], land[ ], or water Spaniel, or any other dog or bitch[] whatsoever, of the English race...."102

Shifting notions of Indian tribal governments served not only direct colonial interests, but also the efforts of the English and American people in theorizing their own societies. Early accounts noted elements of good governance in tribal societies. ${ }^{103}$ Initial negotiations with Indian tribes acknowledged the sovereignty of the tribes, recognizing their leaders as "King" and engaging in a complex set of rituals drawn from both European and tribal notions of diplomacy. ${ }^{104}$ But war helped to transform perceptions of Indians from governments to mobs. A 1675 Massachusetts law, for example, condemned "the manner of the Heathen that are now in Hostility with us, contrary to the practice of the Civil Nations, to execute their bloody [i]nsolencies by stealth and skulking in small parties." ${ }^{105}$ Denigration of tribal lack of governance also helped to define the nature of English and American governmental systems. Thomas Hobbes, in inaugurating modern social contract theory, wrote that "the savage people in many places of America, except the government of small Families, the concord whereof dependeth on naturall lust, have no government at all." ${ }^{\text {106 }}$ As English and Anglo Americans began to theorize themselves as governments of law and consent, tribes were being reconceived as groups bound by blood ties and "naturall lust."

By the 1700 s, ideas of national or cultural difference had merged with those of natural difference, and Indians had become red. The history of this designation, while it indicates racial difference, suggests that it was more

102. Law to Set Limits on Trade With Indians, reprinted in 15 EARLY INDIAN DOCUMENTS, supra nore 72, at 16,17 (reprinting a 1619 law to set limits on trade with Indians).

103. Virginia minister Alexander Whitaker, for example, wrote in 1613 that

there is a civil government amongst them which they strictly observe ... wherein they both honor and obey both Kings, Parents, and Governours, both greater and lesse, they observe the limits of their owne possessions and incroach not upon their neighbours dwellings.

Murther is a capitall crime scarce heard among them: adultery is most severely punished, and so are other offences.

ALEXANDER WHITAKER, GOOD NEVVES FROM VIRGINIA 26-27 (1613), quoted in BERKHOFER, supra note 77 , at 20 .

104. See Conference and Agreement Between Plymouth Colony and Massasoit, Wampanoag, Sachem, reprinted in 19 EARLY INDIAN DOCUMENTS, supra note 72, at 23, 24-26 (describing the procedure resulting in the League of Peace between the Wampanoag and the Plymouth Colony); DANIEL K. RICHTER, FACING EAST FROM INDIAN COUNTRY: A NATIVE HISTORY OF EARLY AMERICA 129-49 (2001) (describing a 1679 treaty negotiation with the Iroquois); Dorothy V. Jones, British Colomial Indicm Treaties, in 4 HANDBOOK OF NORTH AMERICAN INDIANS 185, 185-190 (Wilcomb E Washburn ed., 1988) (summarizing the nature of treaty negotiations between Europeans and Indian Tribes).

105. Law (United Colonies) to Wage War Against "Barbarous Natives", reprinted in 17 EARLY INDIAN DOCUMENTS, supra note 72, at 124.

106. ThOMAS HOBBES, LeVIATHAN 187 (C.B. Macpherson ed., Penguin Books 1986) (1651). 107. Id. 
closely tied to differences of tribal character than individual phenotype. First, the most common description of native skin color was not red but "tawny,"108 and the earliest references to "red skins" invoked Indians adorned with red paint on the war path..$^{109}$ Second, although Carlus Linnaeus classified indigenous Americans as homo rubescus (ruddy or red) in his 1740 Systema Naturae, ${ }^{110}$ he described Indians as "tanned" while Africans were described as "black" and Asians as "yellow." "II Linnaeus' rubescus classification likely reflected his division of the races according to which of the four humors dominated within them, with the "red" Americans designated as "choleric."112 Finally, there is evidence that red may have come from tribal diplomacy. The southeastern tribes referred to themselves as "the red people" and the colonists as "the white people" in diplomatic negotiations. ${ }^{113}$ For these tribes, red signified matters of war, while white signified domestic matters. ${ }^{114}$ Tribal politics was divided between red chiefs who governed war and state, and white chiefs who governed internal matters. ${ }^{115}$ By calling themselves the "red people," these tribal negotiators were both establishing themselves as part of a complementary governmental system and downplaying English skill at war. ${ }^{116}$ Red and white did not have this diplomatic significance among the tribes of the Northeast, and New Englanders in any case were slower to call themselves "white" rather than "Christian."117 But by the nineteenth century, as the division of human beings according to color progressed, red became the universal symbol of the inherent savagery and violence of Indian peoples. ${ }^{118}$

\section{The Rise and Demise of Indian Slavery}

While English Americans were building the ideological and legal structure to support colonization of Indians and their lands, they were also developing an alternative structure to transform African Americans into a permanently inferior labor force. As with domination of Native Americans, religious

108. Nancy Shoemaker, How Indians Got to Be Red, 102 AM. HIST. REV. 625, 629 (1997). The earliest European observers also opined that Indians would be white if only they did not expose themselves to the sun. Kupperman, supra note 81, at 207.

109. See VAUGHAN, supra note 34 , at 25.

110. Shoemaker, supra note 108 , at 626 .

111. HANNARORD, supra note 49, at 204 (quoting CAROLUS LINNAEUS, SYSTEMA NATURAE (1735)).

112. See Shoemaker, supra note 108, at 626 (quoting LINNEAUS, supra note 111).

113. Id. at $627-28$.

114. Id. at 632 .

115. Id.

116. Id. at $640-41$.

117. Id. at 631.

118. See VAUGHAN, supra note 34 , at 4 . 
difference and contract initially justified enslavement of the Africans. ${ }^{119}$ Within a few decades, however, the religious justification faded from significance to protect the contractual interests of the English whose slaves had been baptized. ${ }^{120}$ By the end of the century, contract had merged with the prerogatives of race, creating presumptions of slavery for people of color, and imposing legal and social restrictions on those who were free. ${ }^{121}$

Throughout much of the colonial period, the growth of a racial laboring caste fully included Indians. After the 1636 war with the Pequots and again after King Philip's War of 1675-1676, New Englanders sold the defeated Indians to the Caribbean Islands or gave them to colonists in slavery. ${ }^{122}$ Massachusetts' 1641 law disavowing slavery in the colony, while it did not use racial terms, included two exceptions that neatly excluded Indian and black slaves: one for "lawfull Captives taken in just warres" and another for "such strangers as willingly selle themselves or are sold to us." ${ }^{123}$ Between 1688 and 1753, a variety of Massachusetts laws regulated Indian, negro, and mulatto servants and slaves. ${ }^{124}$

The affirmation of race-based slavery appears to coincide with the growth of restrictions on free Indians along with other people of color. Although colonial laws always included a number of restrictions on Indians, most, like the pervasive restrictions on sales of alcohol, might be construed as protective of both Indians and English. ${ }^{125}$ But by the mid 1700 s, these laws were joined by purely racial restrictions on free Indians and African Americans, such as the 1745 law

119. See JORDAN, supra note 55 , at 55-56, 67-68.

120. 2 William Waller HeNing, THE STATUTES at LARGE; Being a COLleCtion Of ALL THE LAWS OF VIRGINIA, FROM THE FIRST SESSION OF THE LeGISLATURE IN THE YEAR 1619, at 260 (1823) (reprinting a 1667 law providing that those born enslaved would not be freed by baptism).

121. See Law to Regulate Servants and Slaves, reprinted in 15 EARLY INDIAN DOCUMENTS, supra note 72, at 114-22 (reprinting an Oct. 23, 1705 Virginia law regarding slavery and restrictions on free people of color); Law to Regulate Slaves, reprinted in 16 EARLY INDIAN DOCUMENTS, supra note 72, at 120 (reprinting a 1696 South Carolina law establishing the presumption of slavery).

122. See Michael L. Fickes, "They Could Not Endure That Yoke": The Captivity of Pequot Women and Children After the War of 1637, 73 NEW ENG. Q. 58, 59-61 (2000); JORDAN, supra note 55, at 68-69 (discussing the sale of Indians in exchange for Black slaves); Law to Conduct Hostilities, reprinted in 17 EARLY INDIAN DOCUMENTS, supra note 72, at 43-44; Law to Apportion Enemy Prisoners, reprinted in 17 EARLY INDIAN DOCUMENTS, supra note 72, at 47; Order to Regulate Captive Indians, reprinted in 17 EARLY INDIAN DOCUMENTS, supra note 72, at 48-49; Law to Further Regulate Captive Indians, reprinted in 17 EARLY INDIAN DOCUMENTS, supra note 72, at 49.

123. Law to Prevent "Bond Slaverie" in the Colony, reprimted in 17 EARLY INDIAN DOCUMENTS, supra note 72 , at 86 .

124. Law to Punish Commerce in Stolen Goods, reprinted in 17 EARLY INDIAN DOCUMENTS, supra note 72, at 154. Where southern laws typically listed "negroes" first in the list of races affecting slaves, the Massachusetts laws typically list Indians first, and a 1712 law refers solely to "Indians and other slaves." See, e.g., Law to Prohibit the Importation of Indians, reprinted in 17 EARLY INDIAN DOCUMENTS, supra note 72 , at 178 .

125. See, e.g., Law to Further Restrict Indian Access to Alcohol, reprinted in 17 EARLY INDIAN DOCUMENTS, supra note 72, at 109 10 (reprinting a 1657 law restricting alcohol sales). 
prohibiting sale of lottery tickets to "any Indian Negroe or Mulatto[ ] or to others on their behalf," the 1779 exclusion of "the Officers and Students of Harvard College, Ministers of the Gospel, Grammar School-Masters, Indians, Negroes and Mulattoes" from the draft, and the 1786 prohibition against joining "in marriage any White person with any Negro, Indian or Mulatto."126

New York statutes first mention Indian slaves in a 1702 law excluding them from the militia, ${ }^{127}$ but fix their status more explicitly in 1706, dismissing the "Iglroundless opinion that hath spread itself in this Colony, that by the Baptizing of such Negro, Indian or Mulatto slave they would become free" and decreeing that

every Negro, Indian, Mulatto and Mestee Bastard Child and Children who is, are, and shall be born of any Negro, Indian, Mulatto and Mestee, shall follow the State and Condition of the Mother and be esteemed reputed taken and adjudged a Slave and Slaves to all intents and purposes whatsoever. ${ }^{128}$

New York statutes continue to refer explicitly to Indian slaves until 1730 , but do not thereafter. ${ }^{129}$ By 1788 , it was only the children of every enslaved "negro, mulatto or mestee woman" whose condition followed that of the mother. ${ }^{130}$ In the other Northern colonies, the only explicit references to Indian slaves after the early 1750 s are the revolutionary era laws regulating manumission. By 1784, moreover, when Rhode Island authorized the gradual termination of all slavery as repugnant to the natural rights of mankind, it referred only to

126. Order to Exclude Indians From Participation in the Lottery, reprinted in 17 EARLY INDIAN DOCUMENTS, supra note 72, at 193; Resolve to Exclude Indians From Troops to Be Raised, reprimted in 17 EARLY INDIAN DOCUMENTS, supra note 72, at 212; Law to Prohibit Interracial Marriages, reprinted in 17 EARLY INDIAN DOCUMENTS, supra note 72, at 213. As Jack Forbes has painstakingly documented, moreover, during the colonial and early U.S. era, terms usually identified with Indian or black descent could be used for either: Thus "mulatto" could indicate anyone of mixed racial heritage, including Indian and white, while "half-breed" could indicate white and black heritage, and "sambo," now signifying African American, meant black and Indian heritage. JACK D. FORBES, AFRICANS AND NATIVE AMERICANS: THE LANGUAGE OF RACE AND THE EVOLUTION OF RED-BLACK PEOPLES 162, 234-38 (1993).

127. Law to Exclude Indian Slaves and Servants From Militia, reprinted in 17 EARLY INDIAN DOCUMENTS, supra note 72 , at 538 .

128. Law to Encourage the Baptizing of Slaves, reprinted in 17 EARLY INDIAN DOCUMENTS, supra note 72, at 542 (internal citations omitted).

129. Law to Control Slaves and Freedmen, reprinted in 17 EARLY INDIAN DOCUMENTS, supra note 72, at 590-91 (reprinting a 1730 law regulating "Negro, Indian or Mulatto Slaves").

130. Law to Continue and Regulate Slavery for Mestizos and Others, reprinted in 17 EARLY INDIAN DOCUMENTS, supra note 72, at 642. Although in the shifting legal definitions of the time the categories of mulatto and mestizo might have included those of solely Indian and white parentage, the omission of Indian makes it more likely that both referred to those of at least partly African parentage, and that slavery was no longer an inheritable condition among Indians in New York. 
the future enslavement of "negroes, mulattoes, and others." ${ }^{131}$ Indian slavery was surely also prohibited by the law, but was not significant enough to warrant particular mention.

After a slow start, southern laws regarding Indian slavery were both more numerous and more virulent. Although Virginia enacted laws regarding Indian servants within a few years of its founding, a 1670 statute declared that Indians sold after being brought by land could only be servants for years and not slaves for life. ${ }^{132}$ Indians brought by sea, however, could be sold as slaves and were included in a $\mathbf{1 6 7 2}$ law indemnifying those who killed or maimed any runaway "negro, mulatto, Indian slave, or servant for life" during pursuit. ${ }^{133}$ The exception for Indians brought by land was erased by 1682 , when all servants brought into the country "either by sea or land, whether Negroes, Moors, Mulattos or Indians, whose parentage and native country are not Christian at the time of their first purchase ... are hereby adjudged, deemed and taken ... to be slaves to all intents and purposes."134 From this point through 1748, Indians were explicitly included in Virginia laws regarding the property status, restrictions on, and punishments for, slaves.

The Carolinas and Georgia, founded after Indian slavery had been established in Virginia, adopted the institution enthusiastically. As in West Africa, where Africans facilitated the slave trade by capturing members of other African tribes, so in the southern United States tribes such as the Yamasee and Westo gained profit and political power by selling members of other tribes to the colonists. ${ }^{135}$ The colonists, meanwhile, gladly purchased the Indians, both to trade to South America and the northern colonies, and to contribute to the captive labor force. ${ }^{136}$ In 1696 , South Carolina decreed that "all Negroes Mollatos and Indians which at any time ... have been bought and Sold ... for Slaves are hereby made and Declared they and their children Slaves to all

131. Law to Terminate Slavery, reprinted in 17 EARLY INDLAN DOCUMENTS, supra note 72, at 476,477 .

132. Law to Enslave Certain Indians, reprinted in 15 EARLY INDIAN DOCUMENTS, supra note 72, at 73. It should be noted, however, that these times of servitude were far longer than the maximum imposed on servants from Christian countries. A 1658 tax law also suggested that while Indians were servants, Africans were presumed to be slaves. Law to Include Indian Servants Among Tithables, reprimted in 15 EARLY INDIAN DOCUMENTS, supra note 72, at 51 . The law imposed a tax on "all negroes imported whether male or female, and Indian servants male or female however procured ... such christians onelie to be excepted as are natives of this country [for example, English born in Virginia], or such as are imported free either by parents or otherwise ...." Id. (internal citation omitted).

133. Law to Suppress Rebellious Slaves, reprinted in 15 EARLY INDIAN DOCUMENTS, supra note 72, at 74 .

134. Law to Define Slave Status, reprimted in 15 EARLY INDIAN DOCUMENTS, supra note 72, at 88.

135. See Alan Gallay, THE INDIAN SLAVE TRADE: THE RISE OF THE ENGLISH EMPIRE IN THE AMERICAN SOUTH, 1670-1717, at 41, 80 (2002).

136. See, e.g., id. at $41,49,56,127-28$. 
Intents and Purposes ...." ${ }^{137}$ Similarly, a 1740 enactment declared "all negroes and Indians, ... mulattoes or mustizoes who now are, or shall hereafter be, in this Province, and all their issue and offspring, born or to be born, shall be, and they are hereby declared to be, and remain forever hereafter, absolute slaves, and shall follow the condition of the mother," with only "Indians in amity with this government" excluded from the edict. ${ }^{138}$

North Carolina similarly classified Indians along with those of African descent as slaves. ${ }^{139}$ Georgia prohibited slavery to protect white emigrants between 1730 and 1755, but its first slave laws included Indian slaves..$^{140}$ The growth of Indian slavery also appears linked to the inclusion of Indians in restrictions on free people of color, such as prohibitions on the right to vote, hold office, or testify in court, and against marriage or sexual relations between whites and those of another race. ${ }^{141}$

With the exception of Georgia, however, these laws follow the pattern of New York: Until the 1750s, Indians are emphatically declared slaves for life, but after the mid-1700s, slave laws refer only to negroes, mulattos, and sometimes mestizos. ${ }^{142}$ Although these colonies never prohibited enslavement of Indians, it seems clear that Indian slavery fell out of favor. This is not the result of a suddenly improved perception of Indians; references to "skulking" or "barbarous"

137. Law to Regulate Slaves, reprinted in 16 EARLY INDIAN DOCUMENTS, supra note 72, at 121 .

138. Law to Regulate Slaves, reprinted in 16 EARLY INDIAN DOCUMENTS, supra note 72, at 297-98. Even this law, however, suggests that race was not quite the badge of slavery for Indians as it was for Africans: While Africans and mulattos claiming freedom had the burden of proof in claiming this status, Indians claiming freedom because they were in amity did not. See id. at 298.

139. See Law to Regulate Servants and Slaves, reprinted in 16 EARLY INDIAN DOCUMENTS, supra note 72 , at 31 .

140. Law to Regulate Slaves, reprinted in 16 EARLY INDIAN DOCUMENTS, supra note 72, at 381 .

141. For example, see Law to Regulate Slaves and Proscribe Intermarriage, reprinted in 15 EARLY INDIAN DOCUMENTS, supra note 72, at 93, Law to Regulate and Punish Slaves, reprinted in 15 EARLY INDIAN DOCUMENTS, supra note 72, at 148, 153, and Law to Establish Indians' Roles in Court, reprinted in 15 EARLY INDIAN DOCUMENTS, supra note 72, at 159, 160, reprinting Virginia laws regarding intermarriage, voting, and testimony. For North Carolina laws regarding the same, see Law to Deny Suffrage to Indians, reprinted in 16 EARLY INDIAN DOCUMENTS, supra note 72, at 13, Law to Prohibit Colonists From Marrying Indians, reprinted in 16 EARLY INDLAN DOCUMENTS, supra note 72, at 29, and Law to Limit Indian's Roles in Court, reprinted in 16 EARLY INDIAN DOCUMENTS, supra note 72, at 45. For South Carolina laws regarding voting and testimony, see Law to Determine Eligibility for Political Participation, reprinted in 16 EARLY INDIAN DOCUMENTS, supra note 72, at 201-02, and Law to Regulate Slaves, reprinted in 16 EARLY INDIAN DOCUMENTS, supra note 72 , at 297,301 .

142. See, e.g., Law to Regulate Servants and Slaves, reprinted in 15 EARLY INDIAN DOCUMENTS, supra note 72 , at 195-96 (reprinting a 1753 Virginia law reenacting a 1748 law regarding the regulation of slaves, but referring only to "negro[ ] and mulatto[]" slaves); Law to Further Modify Regulation of Slaves, reprinted in 16 EARLY INDIAN DOCUMENTS, supra note 72, at 324, 326 (reprinting a 1751 South Carolina law regarding poisoning by slaves referring only to "every negro, mulatto, and mestizo"). 
Indians and rewards for Indian scalps even increase in this period. ${ }^{143}$ Instead, the laws reflect the increasing tensions between Indian slavery and the demands of colonialism, and the different needs for Indian and black peoples.

Enslavement had never sat easily with the religious conversion justification for colonization. But moral scruples alone would not have checked Indian slavery had it not been for the practical difficulties it posed. Indian servants and slaves could more easily escape and blend in with the local indigenous populations. Ravaged by unfamiliar European diseases, Indians may also have been more likely to die in captivity than the African slaves who had survived the Middle Passage. ${ }^{144}$ Indian men, moreover, might not have had the agricultural skills that Africans brought from their home countries. The lesser value of Indian slaves is reflected in the efforts of New England colonies to trade Indian captives for black ones, ${ }^{145}$ differing compensation paid to the owners of runaway Indian and black slaves killed in attempted capture in Virginia, ${ }^{146}$ and the lesser property taxes paid on Indian slaves in South Carolina. ${ }^{147}$

Equally important, the enslavement of Indians increased the ever present risk of war with local tribes. ${ }^{148}$ This truth was forcefully brought home in the 1750s. Starting in 1754 , the colonies were embroiled in the Seven Years or French and Indian War, in which many tribes joined with the French. ${ }^{149}$ Even after the English forces defeated the French, coordinated attacks by numerous tribes in the Midwest won a royal prohibition against settlement west of the

143. See, e.g., Law to Reward Killing of Indians, reprinted in 15 EARLY INDIAN DOCUMENTS, supra note 72, at 199 (reprinting a 1755 Virginia law referring to "sculking" and "barbarous" natives); Law to Reward the Killing of St. Johns or Cape Sable Indians, reprinted in 17 EARLY INDIAN DOCUMENTS, supra note 72, at 192 (reprinting a 1744 Massachusetts law providing one hundred pounds for Indian scalps); Law to Reward the Capture or Scalping of Enemies, reprinted in 17 EARLY INDIAN DOCUMENTS, supra note 172, at 621 (reprinting a 1746 New York law referring to "Inhuman" Indian practices and providing rewards for Indian scalps).

144. See BLACKBURN, supra note 49, at 141.

145. JORDAN, supra note 55, at 69.

146. E.g., Law to Suppress Rebellious Slaves, reprinted in 15 EARLY INDIAN DOCUMENTS, supra note 72 , at 74 .

147. E.g., Law to Levy Taxes on Slaves and Other Property, reprinted in 16 EARLY INDIAN DOCUMENTS, supra note 72, at 211 .

148. A 1712 Massachusetts law, for example, sought to discourage the importation of Indian slaves, declaring that as the "Indians and other slaves" were "of a malicious, surley and revengeful spirit, rude and insolent in their behavior," an increase in their numbers "is likely to prove of pernicious and fatal consequence ... this province being differently circumstanced from the plantations in the islands, and having great numbers of the Indian natives of the country within and about them." Law to Prohibit the Importation of Indians, reprinted in 17 EARLY INDIAN DOCUMENTS, supra note 72, at 178.

149. Francis Paul PruCha, 1 THE Great Father:The UNITED STATES GOVERNMENT AND AMERICAN INDIANS 21 (1984); The war was called the French and Indian War by the English, but the Seven Years War by the French. Indian tribes did not uniformly ally with the French, but rather exploited the strategic advantages of diplomatic alliances with the various imperial powers. See RICHTER, supra note 104 , at 15460 . 
Appalachians. ${ }^{150}$ Although hundreds of Indian slaves were taken during the French and Indian War, Indian slavery generally disappeared from colonial statutes and policy.

During the last half of the eighteenth century, African race was further entrenched as the badge of slavery and Indian slavery faded from memory and practice. At the same time, the increasing colonial population and speculation in North American land created greater needs for the efficient absorption of tribal territories, and the growth of ideologies insisting on the inferiority of the Indian tribe. On the eve of the American Revolution, Indians were the group whose disintegration and absorption would facilitate and justify the march of white American colonization, and Africans were those who would do the work when they got there.

\section{FOUNDING AND RACING THE NATION}

In the century beginning with the Revolutionary War, Americans were transformed from a collection of British colonies to a single American nation. In the same period, ideas of innate racial hierarchy gained greater hold on science, law, and popular thought. Not surprisingly, the two movements influenced each other, as America came to think of itself as a white nation, and national and cultural differences-Mexican and Chinese as well as Indian-became linked with, and understood as, expressions of innate racial differences. Assimilation of Indian individuals was a symbol of this racial triumph, and was aggressively pursued by federal policymakers and occasionally celebrated in popular culture. At the same time, tribes were increasingly understood not as governments, but as "unfortunate race[s]" under federal control. ${ }^{151}$ Part II.A tracks the racialization of the tribe and its members between the Founding and the end of treatymaking in 1871 . Part II.B takes us from the 1870 s to the 1920 s, which saw the growth of federal power in Indian affairs and increasingly coercive efforts at assimilation of Indian individuals, as well as explicit understandings of this federal domination as the formative American experience.

\section{A. 1776-1871: Revolution to Reservation}

In the years between the founding of the American republic and the declaration of the end of treatymaking in 1871, the racial role of American Indians became more fixed and defined. Individual Indians, particularly for

150. See PRUCHA, supra note 149, at 24-25.

151. United States v. Rogers, 45 U.S. (1 How.) 567, 572 (1846). 
communities far removed from native populations, became a symbol of the potential and duty of the American republic. Through civilization and incorporation of the Indian, the white race could both fulfill the sacred obligations that came with Manifest Destiny and partake of the romance of the natural world. Tribes, however, were increasingly treated not as nations or governments, but as collections of individuals joined only by race. Within this divide between the assimilable individual and the racialized tribe, the greatest innate defect of the Indian was the unfathomable insistence on clinging to the barbarous tribe.

The U.S. Constitution reflected the divergent legal places of Africans and Indians in the racial schema of the new nation. Although the constitutional terms relating to these groups are largely intended to allocate power among American states and the branches of the federal government, they provide an apt metaphor for their divergent roles. African American slaves would be inferior individuals, three-fifths of a person, incorporated within American communities. ${ }^{152}$ Indians, however, were mentioned in the Commerce Clause as "Indian [t]ribes," alongside "foreign [n]ations" and the "several [s]tates." This enumeration with states and foreign countries helps to establish tribes as sovereigns, with important legal rights..$^{154}$ Still, as both Indian and tribe, these sovereigns were clearly other, a form of government defined in part, and limited by its racial origin. By the end of this period, much of the sovereign aspect of this role would recede, subsumed by the Indian and tribal.

During the American Revolution, the character of the individual Indian had become more closely associated with the character of America and with Anglo-American claims to independence from Great Britain. Anglo Americans garbed as Mohawks dumped tea into Boston Harbor, and patriotic cartoons frequently pictured America as a noble and imprisoned Indian. ${ }^{155}$ Thomas Jefferson's statements regarding Indians in his 1785 Notes on the State of Virginia, frequently cited as support for the proposition that Native Americans were perceived as biologically equal to whites, in fact emerge from a defense of the white American character. They respond to French scholarship claiming that the small size and inferior quality of American-grown animals, plants, and human beings was evidence that the American environment was detrimental to life, and that, therefore, the American people and their

152. See U.S. CONST. art. I, § 2, para. 3.

153. Id. \& 8, cl. 3 .

154. See Cherokee Nation v. Georgia, 30 U.S. (1 Pet.) 1, 18-19 (1831); Robert N. Clinton, The Dormant Indian Commerce Clause, 27 CONN. L. REV. 1055, 1169-70 (1995).

155. DeLORIA, Playing InDIAN, supra note 29, at 30-32. 
new nation would never amount to much. ${ }^{156}$ Here as elsewhere, adulation of American Indians was often tied to praise for white Americans.

Ultimately, the nationalism that grew during and after the Revolution only increased notions of American superiority over Indian tribes and the justice of Anglo-American claims to the continent. Even those who argued that respect for tribal legal rights was the only path consistent with the honor of the United States saw tribes as a doomed entity, destined to disappear in the face of Anglo-American genius. ${ }^{157}$ This is evident in George Washington's 1783 letter insisting on "the propriety of purchasing [Indian] Lands in preference to attempting to drive them by force," an expediency justified as "the gradual extension of our Settlements will as certainly cause the Savage as the Wolf to retire; both being beasts of prey tho' they differ in shape." ${ }^{58}$ If these beasts of the forests chose not to disappear or assimilate voluntarily, the new nation would help them along. By 1819, Congress had created a permanent fund for civilization of the Indians, stating that: "In the present state of our country one of two things seems to be necessary. Either that those sons of the forest should be moralized or exterminated."159

These opinions do not, in themselves, prove that the limitations placed on Indian tribes were considered innate or racial. They leave open the possibility that an Indian tribe might, by adopting an Anglo-American government and economy, win the right to maintain its existence. The Removal Crisis of the 1820s and 1830s, however, demonstrated that it was only by assimilating as individuals, not members of tribes, that Indians could win a

156. See THOMAS JEFFERSON, NOTES ON THE STATE OF VIRGINIA (1785), reprinted in THE LIFE AND SELECTED WRITINGS OF THOMAS JEFFERSON, at 205-06, 213 (Adrienne Koch \& William Peden eds., 1944). Jefferson's comments in this context, while certainly evidence that representations of Indian race could be manipulated according to American needs, are hardly conclusive evidence of a widespread belief in Indian racial equality. Indeed, immediately after praising America's Indians, Jefferson ensured that his statements could not be taken as a testament to racial equality:

I do not mean to deny that there are varieties in the race of man, distinguished by their powers both of body and mind. I believe there are, as I see to be the case in the races of other animals. I only mean to suggest a doubt, whether the bulk and faculties of animals depend on the side of the Atlantic on which their food happens to grow ....? Id. at 213.

157. For example, Secretary of War Henry Knox opined that taking Indian land without consent would be "a gross violation of the federal laws of nature, and of that distributive justice which is the glory of a nation," 1 AM. STATE PAPERSON INDIAN AFFAIRS 13 (1789), but that "the inevitable consequence of cultivation" was that within "a short period, the idea of an Indian on this side [of] the Mississippi will only be found in the page of the historian." Letter From Henry Knox to George Washington (July 7, 1789), 1 AM. STATE PAPERS ON INDLAN AFFAIRS, supra, at 52, 53.

158. Letter From George Washington to James Duane (Sept. 7, 1783), in DOCUMENTS of UNITED STATES INDIAN POLICY 2 (Francis Paul Prucha ed., 3d ed. 2000).

159. ALICE C. FLETCHER, BUREAU OF EDUC., INDIAN EDUCATION AND CIVILIZATION, EXEC. DOC. No. $48-95$, at 162 (1888). 
place in American society. Federal policy between 1812 and 1850 concentrated on moving tribes west of the Mississippi, where the tribes could "pursue their plan of civilization"160 without interfering with "the natural superiority allowed to the claims of civilized communities over those of savage tribes.",161 But the Cherokee Nation, which refused to sign removal treaties, had all of the characteristics policymakers had designated as those of a civilized community: Its members farmed, engaged in manufacturing, established a common school system, trial and appellate courts, and a constitution, and even held African slaves, perhaps the ultimate symbol of civilization at the time..$^{162}$ Despite this, because the Cherokee Nation refused to give up its tribal status and dissolve into the American populace, the tribe was damned for misusing the gifts of Anglo-American teaching and was ultimately forced across the Mississippi. ${ }^{163}$

Georgia's efforts to extend state jurisdiction over Cherokee territory during the crisis resulted in two powerful Supreme Court opinions: Cherokee Nation v. Georgia $^{164}$ and Worcester v. Georgia. ${ }^{165}$ Justice Marshall's opinion in Worcester in particular affirmed the rights of tribal governments and created a legal precedent that continues to impact Indian law jurisprudence. ${ }^{166}$ But the sentiments that captured future policy were those from Justice Johnson's concurrence in Cherokee Nation v. Georgia. ${ }^{167}$ Johnson opined that there were "strong reasons for doubting the applicability of the epithet state, to a people so low in the grade of organized society as our Indian tribes most generally are," describing Indians at the time of contact as "a race of hunters, connected in society by scarcely a semblance of organic government...."168 Although Johnson admitted that the Cherokee Nation bore little resemblance to this stereotype, he claimed that federal law allowed "no other rights ... than what were needed by a race of hunters ...."169 Indeed, tribal "advancement beyond that state of society" could not be "promoted, or, perhaps, permitted" because "a more fixed state of society

160. S. DOC. NO. 21-61, at $8(1830)$.

161. H.R. REP. NO. 21-227, at 7 (1830).

162. See Letter of Cherokee David Brown (Sept. 2, 1825), quoted in THOMAS L. M'KENNEY, MEMOIRS, OFFCLAL AND PERSONAL; WITH SKETCHES OF TRAVELS AMONG THE NORTHERN AND SOUTHERN INDIANS 38-40 (2d ed. 1846).

163. Bethany R. Berger, "Power Over This Unfortunate Race": Race, Politics and Indium Law in United States v. Rogers, 45 WM. \& MARY L. REv. 1957, 1973-74 (2004).

164. 30 U.S. (1 Pet.) 1 (1831).

165. 31 U.S. (1 Pet.) 515 (1832).

166. See Berger, supra note 163, at 1976-77; Philip P. Frickey, Marshalling Past and Present: Colonialism, Constitutionalism, and Interpretation in Federal Indian Law, 107 HARV. L. REV. 381, 400-04 (1993).

167. Cherokee Nation, 30 U.S. at 20.

168. Id. at 21-22 (Johnson, J., concurring).

169. Id. at 23 . 
would amount to a permanent destruction of the hope" that tribes would ultimately disappear. ${ }^{170}$ Accordingly the only rights Johnson would recognize in tribes were distinctly limited by race, those appropriate to "wandering hordes, held together only by ties of blood and habit."

The permanent disgust in which tribal governments were held was even more pronounced in the states in which they lived. In rejecting the notion that the Cherokee Nation could have exclusive criminal jurisdiction over a crime between two Cherokee citizens, a conference of Georgia judges opined that the "habits, manners, and imbecile intellect of the Indians" opposed their governance as an independent state. ${ }^{172}$ In response to the decision of the Supreme Court to review its jurisdiction over a Cherokee defendant, the state hung the prisoner before an eager crowd on Christmas Eve morning. ${ }^{173}$ At the same time that they were vehemently denying tribal rights, however, the southeastern states began easing the restrictions placed on individual Indians, granting tribal members state citizenship and lifting prohibitions on Indians testifying against whites. ${ }^{174}$

Over the next decades, the Court would emphasize the status of tribes as racial rather than political groups. In 1846 in United States $v$. Rogers, ${ }^{175}$ the Court held that the benefits of tribal membership were limited by race, holding that a white man naturalized as a Cherokee citizen was not an Indian under statutes exempting crimes between Indians from federal jurisdiction. ${ }^{176}$ Tribes, the decision affirmed, were not governments entitled to naturalize citizens of any race, but instead themselves a race subject to federal power. ${ }^{177}$ Although the United States had "exercised its power over this unfortunate race in the spirit of humanity and justice," tribes had "never been acknowledged or treated as independent nations by the European governments ...."178

170. Id.

171. Id. at $27-28$

172. State v. Tassels, 1 Ga. Rep. Ann. 478, 481 (Super. Ct. 1830).

173. See TIM ALAN GARRISON, THE LEGAL IDEOLOGY OF REMOVAL: THE SOUTHERN JUDICIARY AND THE SOVEREIGNTY OF NATIVE AMERICAN NATIONS 119-22 (2002). Like lynchings of African Americans in the Jim Crow period, the hanging was a public spectacle. One observer recalled that, "Every road leading to the town was thronged at an early hour with men and women and children from all parts of the county and many from adjoining counties until a vast multitude was assembled to witness the death of a human being suspended between heaven and earth." Id. at 122.

174. ROSEN, supra note 33, at 113-14, 157.

175. 45 U.S. (1 How.) 567 (1846).

176. See id. at 572-73.

177. See id. (explaining that Indians are an "unfortunate race" subject to federal dominion and control); Berger, supra note 163.

178. Rogers, 45 U.S. at 572. 
Yet individual Indian rights continued to be affirmed by the Supreme Court. Justice Taney even used them as a foil for the African American absence of rights in Dred Scott v. Stanford, ${ }^{179}$ carefully distinguishing between the racial limitations on the rights of Indian tribes and the ability of individual Indians to become naturalized American citizens. Indian tribes, the Court opined, were "under subjection to the white race; and it has been found necessary, for their sake as well as our own, to regard them as in a state of pupilage, and to legislate to a certain extent over them and the territory they occupy." unlike African Americans, Indians could become naturalized citizens by the authority of Congress; indeed, "if an individual should leave his nation or tribe, and take up his abode among the white population, he would be entitled to all the rights and privileges which would belong to an emigrant from any other foreign people."181

Although this period saw the rise of scientific racism as an indelible stain on African Americans, the insistence on Indian ability to achieve equality if separated from their tribes dominated policy pronouncements. The 1843 report of the Commissioner on Indian Affairs, for example, dwelt on the difficulty of getting the various tribes to stay away from their homelands once they had been removed, stating that "[t]he erratic habits of the Indian, and the facility with which the impulse of the moment controls him, occasion great trouble to the department." ${ }^{182}$ The same report, however, declared in a discussion of the Sac and Fox, that "[t]hese men ... came from the hand of their Creator and ours, a noble, manly race. What might not be made of such material, if they could be persuaded to abandon idleness and intemperance, and to know their ignorance?"183

Such affirmation of individual Indian mutability was maintained even among those who, like Henry Schoolcraft, collected and studied Indiąn skulls in the path of eugenicist Samuel Morton. ${ }^{184}$ Schoolcraft was the compiler of a government commissioned report, Information Respecting the History, Condition, and Prospects of the Indian Tribes of the United States. His report blamed the inferior diameter of the Indian skulls in his collection on the detrimental effect of an overly large territory, and claimed that the crania showed "no impediment to such rise in arts and improvements," and gave "full encouragement to the

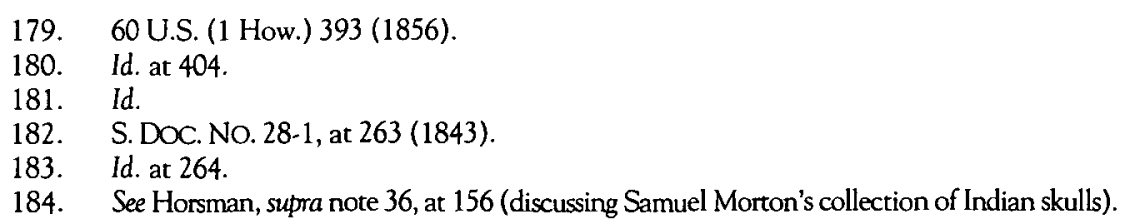


efforts making for their education and moral advancement." ${ }^{185}$ At the same time, Schoolcraft had nothing but disdain for Indian tribes, which he described as "erratic and predatory hordes of hunters, without agriculture, arts, or letters, and with absolutely nothing in their civil polity that merits the name of government." ${ }^{186}$ Indeed, the desire to cling to such backward tribal governments and practices was the true defect of the Indian race:

As a race, there never was one more impracticable; more bent on a nameless principle of tribality; more averse to combinations for their general good .... The same indestructibility of type, the same nonprogressiveness of the Indian oriental mind, is perceived in the race in every part of the continent. ${ }^{187}$

Indian Commissioner William Medill expressed similar sentiments, describing the "full-blood Indian" as "[s]tolid and unyielding in his nature, and inveterately wedded to the savage habits, customs, and prejudices in which he has been reared and trained," but proclaiming that "before many years, if we sacredly observe all our obligations towards them, they will have reached a point at which they will be able to compete with a white population, and to sustain themselves under any probable circumstances of contact or connexion [sic] with it." ${ }^{188}$ The result was to punish Indians while they preserved their "pseudo-nationality," but maintain that "[t]o reclaim such a race to the paths of virtue and truth; to enlighten the mind which has been so long in darkness; and to give it new and solid foundations for its hopes, is a duty alike of high civilization and warm benevolence.".189

This simultaneous condemnation of the incurable barbarity of the tribe and affirmation of the potential of the Indian individual produced the Reservation Policy that dominated federal policy between the 1850s and 1870s. Where Removal sought to transport tribes to unpopulated lands, where (federal negotiators promised) native people could escape intrusion by grasping whites, the Reservation Policy sought to confine them on reservations where they could be forcibly trained to disdain their tribes and emulate Anglo Americans. ${ }^{190}$ Tribes, formerly removed to an ill-defined Indian territory, were now confined on smaller plots of land where they could be "controlled,

185. 3 HENRY R. SCHOOLCRAFT, BUREAU OF INDIAN AFFAIRS, INFORMATION RESPECTING THE HISTORY, CONDITION, AND PROSPECTS OF THE INDIAN TRIBES OF THE UNITED STATES, at vii (Paladin Press 1969) (1853).

186. 1 SCHOOLCRAFT, supra note 185 , at $\mathrm{v}$.

187. Id. at 15,41 .

188. WILlIAM MEDILL, ANNUAL REPORT OF COMMISSIONER OF THE INDIAN AFFAIRS (Nov. 30, 1848), reprinted in DOCUMENTS OF UNITED STATES INDIAN POLICY, supra note 158, at 76, 77-79.

189. 1 SCHOOLCRAFT, supra note 185 , at ix, $x$.

190. See 2005 COHEN, supra note 21 , at $64-65$. 
and finally compelled by stern necessity to resort to agricultural labor or starve."191 Federal agents were dispatched to the reservations to replace tribal governments and culture with white institutions. ${ }^{192}$

While tribes progressively lost equal rights as governments, the racial limitations on Indians as individuals, and even the history of Indian slavery, began to be erased in the ideological battle to justify black slavery. In 1806 in Hudgins v. Wrights, ${ }^{193}$ the Virginia Supreme Court rewrote colonial history to hold that no American Indian could be held as a slave in the colony after 1691 , freeing the petitioner whose descent was Indian and white. ${ }^{194}$ Similarly in 1838 and 1848 decisions, again in contradiction of the language of the statutes construed, the South Carolina Supreme Court held that all free Indians, not only those that could prove their connection with a particular tribe, could take advantage of the rights of "free Indians in amity with the government" and testify in court. ${ }^{195}$ Across the South, slaves sought to prove that they were of Indian, not black, descent in litigating suits for freedom..$^{196}$

191. Id. at 64 (quoting COMM'R IND. AFF. ANN. REP., S. EXEC. DOC. NO. 31-1 (1850)).

192. See Berger, supra note 163, at 2017.

193. 11 Va. (1 Hen. \& M.) 133 (1806).

194. See id. at 139. The decision was based in part on a 1793 case, which had held that no Indian could be made a slave after 1705 when a law authorized free trade with the Indians. See Coleman v. Dick \& Pat, 1 Va. (1 Wash.) 233 (1793). Even this decision is in contrast with the rest of the statutes of the time, most glaringly with the laws passed that same session declaring that "all negro, mulatto, and Indian slaves... shall be held, taken and adjudged, to be real estate (and not chattels)" and that all non-Christian servants, except Turks and Moors, brought into the country by sea or land would be held as slaves. Law to Declare Slaves to Be Real Estate, reprinted in 15 EARLY INDIAN DOCUMENTS, supra note 72, at 112; Law to Regulate Servants and Slaves, reprinted in 15 EARLY INDIAN DOCUMENTS, supra note 72, at 114-15. Both decisions may be excused in part by the apparent inaccessibility of the colonial statutes - Justice Tucker wrote that he did not actually have a complete copy of the 1691 statute, but that a clerk had certified that the free trade provision was the same as that in the 1705 law. Hudgins, $11 \mathrm{Va} .(1$. Hen. \& M.) at $138 \mathrm{n} .1$. It is more likely, however, that the statutorily erroneous decision was based on the difficulty for abolitionist justices like Justice Tucker in upholding slavery, and the desire to have any positivist reason for outlawing it, while reserving it for the African Americans that the statutes had clearly designated as slaves. See ROBERT M. COVER, JUSTICE AOCUSED: ANTISLAVER Y AND THE JUDICIAL PROCESS 51-55 (1975) (discussing the formalist/moral dilemma of Hudgins). Modem scholars, however, have tended to accept Tucker's erroneous holding that Indians could not be held as slaves in Virginia after 1691. See, e.g., Davis, supra note 5, at 703; A. Leon Higginbotham, Jr. \& Barbara K. Kopytoff, Racial Purity and Interracial Sex in the Law of Colonial and Antebellum Virginia, 77 GEO. LJ. 1967,1973 n.24 (1989). A 1772 decision holding that Indians could not be enslaved in Virginia after 1705 has a far more complete and accurate discussion of the relevant statures to that time in the arguments of the parties, but the one paragraph decision gives no indication of why the judges accepted the tortured reasoning of the plaintiff as opposed to the more legally accurate reasoning of the defendant. See Robin v. Hardaway, 1 Jeff. 109 (Va. 1772).

195. See Miller v. Dawson, 23 S.C.L. (Dud.) 174 (1837).

196. For a discussion of these cases, see Ariela J. Gross, Litigaing Whiteness: Trials of Racial Determination in the Nineteench-Century South, 108 Y ALE LJ. 109, 141-51 (1998). The racial attitudes toward Indians could, however, in different circumstances, slip into justifications of slavery. During the brutal California gold rush, slavers raided Indian villages and Indians captured were indentured 
Interactions between Indian and black were also increasingly defined by their divergent racial roles. During the colonial period, Indians and blacks were often natural allies. The praying town of Mashpee, for example, so intermingled the Indian survivors of disease and war with free blacks denied rights in white communities that legislation protecting the town referred to "the Indians and molattoes, inhabitants and proprietors of Mashpee ...."197 In North Carolina, the Lumbee Indians incorporated not only members of other tribes, but also free and runaway Africans and Scotch colonists, while in Florida, Africans joined with Seminoles in their vigorous resistance to colonization of their land. ${ }^{198}$

In the nineteenth century, however, these groups were often dismissed as remnants without tribal rights. In 1835, North Carolina enacted laws restricting the rights of "free persons of color" in part to restrict the Lumbee Indian community, which they dubbed the "mulattoes of Robeson County." The Narragansetts of Rhode Island fought a losing battle to preserve tribal rights and land in the face of claims that intermarriage with African Americans had "mongrelized" the tribe out of existence. ${ }^{200}$ Even the powerful Seminole tribe was condemned as being overly influenced by the non-Indians that had joined it. ${ }^{201}$ While some tribes responded to such efforts by claiming Indian to the exclusion of African heritage, others turned to claims of national and political status independent of race. ${ }^{202}$ At the same time, members of southeastern tribes began employing black slave labor to till the fields in the large-scale agriculture that white American culture encouraged. ${ }^{203}$ Although

for up to sixteen years upon payment of a two dollar fee, resulting in enslavement of as many as ten thousand California Indians. FERGUS M. BORDEWICH, KILLING THE WHITE MAN'S INDIAN: RENVENTING NATIVE AMERICANS AT THE END OF THE TWENTIETH CENTURY 50-51 (1996). Interestingly, legal restrictions on California Indians are far more similar to those placed on African Americans in other parts of the country.

197. 17 EARLY INDIAN DOCUMENTS, supra note 72, at 204. Similarly, the Cuffees were one of the core families of the Shinnecock tribe of Long Island, helping to preserve the language and traditions of the tribe. See M.R. Harrington, Shinnecock Notes, 16 J. AM. FOLKLORE 37, 37, 39 (1903). "Cuffee," however, was an African name that slaves often gave their children.

198. See Joyce A. McCray Pearson, Red and Black: A Divided Seminole Nation, 14 KAN. J.L. \& PUB. POL'Y 607, 609-20 (2005) (describing black participation in Seminole history).

199. See Karen I. Blu, The LUmbee Problem: The Makinc of an american Indian PEOPLE 45-47, 64 (1980).

200. See Ariela Gross, "Of Portuguese Origin": Litigating Identity and Citizenship Among the "Little Races" in Nineteenth-Century America, 25 L. \& HIST. REV. 467, 506-08 (2007).

201. See Berger, supra note 163, at 2032.

202. See Gross, Portuguese Origin, supra note 200, at 498, 506 (describing Lumbee efforts to deny any African heritage and Narragansett efforts to deny that it was relevant). Gross also describes the Melungeons, who responded to efforts to classify them as negro by claiming solely white and Portuguese heritage. Id. at 481-98. Because Gross discusses largely the different claims and reactions to those claims made by the different groups, but not the way those claims may have related to phenotypic differences or differences of political community, it is hand to identify the reasons for these different choices.

203. See William McLoughlin, Red Indians, Black Slavery, 26 AM. Q. 367, 368 (1974). 
slaveholding remained limited to the more assimilated tribal members, it was these members who drafted the tribes' written laws, and the "Civilized Tribes" soon had slave codes modeled on those of the southern states. ${ }^{204}$

Responses to Indian-white intermarriage provide one of the clearest contrasts between treatment of Indians and African Americans. In the colonial period, southern states had condemned the "abominable mixture and spurious issue" of white and Indian. ${ }^{205}$ Indians, however, vanished from Virginia's anti-miscegenation law in 1753 , the same year they disappeared from its slavery laws. ${ }^{206}$ Throughout the first half of the nineteenth century, moreover, southern courts recognized rights stemming from Indian-white marriages. ${ }^{207}$ In the buildup to the Civil War, southerners positioned themselves as the descendants of John Rolfe and Princess Pocahontas to locate the Confederacy as a truly American aristocracy. ${ }^{208}$ Henry Schoolcraft himself boasted that marriage to his "highly educated" Indian wife, who, he was careful to note, was the granddaughter of a "distinguished aboriginal chief-regnant, or king," had given him special insight into the Indian mind. ${ }^{209}$

Intermarriage was only tolerated, however, as a means for Indians to leave their tribes and merge with the white race. As seen in the Rogers case, those who had married native people and remained with the tribes of their spouses were condemned as degenerate, the "most mischievous and dangerous inhabitants of the Indian country." 210 Nor were Indian men acceptable partners for white women: In both the husband-wife relationship and the Indian-white relationship, power and influence was to be concentrated on one side; shifting

204. Berger, supra note 163, at 2021-24; see MCLOUGHLIN, supra note 35, at 338-47 (describing the development of anti-Black prejudice among the Cherokees).

205. See, e.g., Law to Regulate Slaves and Proscribe Intermarriage, reprinted in 15 EARLY INDIAN DOCUMENTS, supra note 72 , at 93.

206. See, e.g., Law to Regulate Servants and Slaves, reprinted in 15 EARLY INDIAN DOCUMENTS, supra note 72 , at 93 .

207. See, e.g., Wells v. Thompson, 13 Ala. 793 (1848) (holding that a white man who had married a Creek woman and abandoned her, which would constitute divorce under Creek law, was not legally divorced and therefore could inherit and sell her allotment); Johnson v. Johnson's Adm'r, 30 Mo. 72 (1860) (holding that the thirty-year cohabitation of a white man and an Indian woman was a valid marriage under Indian custom, so that their children were legitimate and were entitled to inherit despite the claims of the white woman that the father had later married under state law); Morgan v. McGhee, 24 Tenn. (1 Hum.) 13 (1844) (holding that because a Cherokee woman and a white man were validly married, she was a femme couvert and therefore could not sue to enforce a contract).

208. REBECCA BLEVINS FAERY, CARTOGRAPHIES OF DESIRE: CAPTIVITY, RACE, AND SEX IN THE SHAPING OF AN AMERICAN NATION 114 (1999).

209. 1 SCHOOLCRAFT, supra note 185 , at xi.

210. United States v. Rogers, 45 U.S. (1 How.) 567, 573 (1846); see Berger, supra note 163, at 1969, 2033. 
the equation violated not only sexual mores, but also the political order. ${ }^{211}$ This selective and highly gendered acceptance of intermarriage was therefore fully consistent with the racialization and inferiority of the Indian tribe. So Thomas Jefferson, who told the Delawares to "mix with us by marriage, your blood will run in our veins, and will spread over this great island,"212 also argued that Indians must "either incorporate with us as citizens of the United States, or remove beyond the Mississippi," and that tribes who resisted would be driven across the Mississippi as "an example to others, and a furtherance of our final consolidation." ${ }^{213}$ Intermarriage and removal were simply different means to the same end: the dominance and eventual disappearance of the Indian tribe.

Popular culture in the mid-nineteenth century also revealed the complexity of white views of intermarriage and Indians themselves. The noble savage was a favorite subject of romantic artists and writers, as exemplified by George Catlin's portraits and Henry Wadsworth Longfellow's Hiawatha. ${ }^{214}$ But once in contact with white civilization, only those Indians who sacrificed their tribal identities-and often their lives-to white interests were tolerated. Pocahontas, who married John Rolfe and converted to Christianity before dying of small pox, was a popular theme, and in 1840 John Chapman's Baptism of Pocahontas at Jamestoun, Virginia was hung in the capitol rotunda. ${ }^{215}$ Similarly, Ann Sophia Stephens' Malaeska; The Indian Wife of the White Hunter, the inaugural bestseller of the dime novel craze ${ }^{216}$ idealizes the doomed Indian protagonist who, through her "humble submission" to her white husband, "combined all that was strong, picturesque, and imaginative in savage life, with the delicacy, sweetness, and refinement which follows in the train of

211. As an example, consider the treatment of Cherokees Elias Boudinot and John Ridge and their white wives. The American Missionary Board, committed to the assimilation and equality of Indians, brought Ridge and Boudinot to their Connecticut academy for higher education. But when the Cherokees proposed to the white women who would become their wives, the Academy expelled the offending students and the community burnt one of the couples in effigy. See MCLOUGHLIN, supra note 35, at 367-68; see also Kevin Noble Maillard, The Pocahontas Exception: The Exemption of American Indian Ancestry From Racial Purity Law, 12 MiCH. J. RACE \& L. 351, 359 (2007) (discussing the reactions of the brother-in-law of Boudinot's wife).

212. Letter From Thomas Jefferson to Captain Hendrick, the Delawares, Mohiccons, and Munries (Dec. 21, 1808), in THE COMPLETE JEFFERSON 503 (Saul K. Padover ed., 1943).

213. Letter From Thomas Jefferson to William Henry Harrison (Feb. 27, 1803), in DocumENTS OF UNITED STATES INDIAN POLICY, supra note 158 , at 22-23.

214. BERKHOFER, supra note 77, at 89-90.

215. SUSAN SCHECKEL, THE INSISTENCE OF THE INDIAN: RACE AND NATIONALISM IN NINETEENTH-CENTURY AMERICAN CULTURE 139-40 (1998).

216. See BERKHOFER, supra note 77, at 99; Bill Brown, Introduction to ANN SOPHIA STEPHENS, MALAESKA: THE INDIAN WIFE OF THE WHITE HUNTER (1860), reprinted in READING THE WEST: AN ANTHOLOGY OF DIME WESTERNS 54-55 (Bill Brown ed., 1997). 
civilization." ${ }^{217}$ As in the westerns that soon followed Malaeska, ${ }^{218}$ however, Indians who remain allied with their tribes were hardly human, characterized by a "demoniac thirst for blood," 219 with their "savage yell" upon being interrupted during a war council "as if a company of fiends had been disturbed in their orgies." ${ }^{220}$

Like Malaeska, the individual Indian was a figure who, properly guided, would enable the expanding American nation to combine the beauty and wisdom of the natural world with the refinement of civilization. Without such humble submission, however, Indians were nothing more than an "unfortunate race," to be civilized if possible, and exterminated if not. By 1871, Congress had prohibited further treatymaking with Indian tribes. ${ }^{221}$ The direct catalyst of this law was a conflict between the U.S. House and Senate regarding Indian policy, and existing treaties remained in full force. ${ }^{222}$ But the law effectively symbolized what Indian policy had made increasingly clear: Having begun the century as nations negotiating with the United States, tribes were no longer regarded as governments, but instead as "wandering hordes, held together only by ties of blood and habit...."223 Law, policy, science, and culture thus joined in a coherent picture: While the legal and social status of the Indian individual would shift by context, the racialized inferiority of the Indian tribe would be increasingly inflexible.

\section{B. 1871-1928: Assimilation and Oppression}

The Jim Crow Era for African Americans was the Allotment and Assimilation Era for Native Americans. During the 1870s and 1880s, the military confined the last independent tribes on reservations, and in 1890 , Wounded Knee marked the end of the Indian wars. With the waning of a significant military threat, policymakers would regulate tribes and Indian individuals more forcefully than ever before in the quest to separate the Indian from the tribe. Courts obliged by eliding the limitations that tribal sovereignty and treaties had placed on federal action. Historians self-consciously designated the triumph over Indian tribes as the formative experience of the white American race. Although assimilating Indians frequently confronted

217. STEPHENS, supra note 216 , at $76,124$.

218. See BERKHOFER, supra note 77 , at 99-100.

219. STEPHENS, supra note 216, at 74 .

220. Id. at 73 .

221. See Act of Mar. 3, 1871, ch. 120, $\$ 1,16$ Stat. 570 (1871) (codified at 25 U.S.C. $\S 71$ (2006)).

222. See 2005 COHEN, supra note 21, at 74-75.

223. Cherokee Nation v. Georgia, 30 U.S. (1 Pet.) 1, 26-28 (1831) (Johnson, J., concurring). 
color prejudice, individual examples of Indian assimilation were celebrated in academic and cultural arenas, opening doors wholly closed to other races.

Federal Indian policy, which previously vacillated between sovereign and racialized views of tribes, moved decisively toward the latter. The 1887 Dawes Allotment Act was the defining legislation of the era. The Act authorized the federal government to divide remaining tribal territories among individual Indian households, with land not divided declared surplus and free for white acquisition. ${ }^{224}$ Although the policy was supported as a means to open reservation land to white settlement, it was also "inspired by the highest motives" and "regarded as a panacea which would make restitution to the Indian for all that the white man had done to him in the past."225 The law was "a mighty pulverizing engine for breaking up the tribal mass" individual from the tribe. ${ }^{227}$

This direct intrusion on tribal economies was accompanied by coercive efforts directed toward the "ultimate absorption of the Indian race into the body politic of the nation."228 Federal agents created tribal police forces and courts staffed with trusted Indians for the same purpose, to establish "a power entirely independent of the chiefs" and thereby "finally destroy, the power of tribes and bands." ${ }^{229}$ Indian children were taken from their families and placed in boarding schools to enable the individual to overcome the fatal allure of the tribal community. Captain Richard Pratt, founder of the Carlisle Indian School, described the goal of the schools: "[A]ll the Indian there is in the race should be dead. Kill the Indian in him and save the man." in the Indian race was to kill the tribe, by planting "treason to the tribe and loyalty to the nation at large."231

The Supreme Court generally supported and provided justification for these policies. In a series of decisions, the Supreme Court further diminished the sovereign element of the Indian tribe to emphasize the racially Indian. In 1886,

224. Dawes Allotment Act, 24 Stat. 388-91 (1887).

225. D.S. OTIS, THE DAWES ACT AND THE ALLOTMENT OF INDIAN LANDS 8 (Francis Paul Prucha ed., 1973) (1934).

226. Merrill E. Gates, Addresses at the Lake Mohonk Conferences (1900), reprinted in AMERICANIZING THE AMERICAN INDIANS, supra note 24, at 342.

227. See Kenneth H. Bobroff, Retelling Allotment: Indian Property Rights and the Myth of Common Ounership, 54 VAND. L. REV. 1559, 1564-70 (2001).

228. See 1917 COMM'R INDIAN AFFAIRS ANN. REP. 3-5, reprinted in DOCUMENTS OF UNITED STATES INDIAN POLICY, supra note 158, at 214.

229. WILLIAM T. HAGAN, INDIAN POLICE AND JUDGES: EXPERIMENTS IN ACCULTURATION AND CONTROL 79 (1980) (quoting an 1881 report of Commissioner Hiram Price).

230. RICHARD H. PRATT, INDIAN EDUCATION, reprinted in AMERICANIZING THE AMERICAN INDIANS, supra note 24, at 263.

231. Id. at 269. 
United States v. Kagama ${ }^{232}$ held that Congress could enact legislation governing crimes between tribal members on reservations. ${ }^{233}$ The Court stated that there were just two sovereigns within the geographical limits of the United States, the states and the federal government, and as for Indians, the "power of the [federal] government over these remnants of a race once powerful, now weak and diminished in numbers, is necessary to their protection. ${ }^{1234}$

In Lone Wolf v. Hitchcock ${ }^{235}$ in 1903, the Court quoted this language to hold that Congress could unilaterally abrogate tribal treaty rights and exchange their territory for allotments and money. ${ }^{236}$ Recognizing that the diminishment of tribal rights was for American Indians the equivalent of denying individual rights to African Americans, a protesting Senator called Lome Wolf the "Dred Scott decision No.2, except that in this case the victim is red instead of black. It practically inculcates the doctrine that the red man has no rights which the white man is bound to respect, and, that no treaty or contract made with him is binding." ${ }^{237}$ The logic of these decisions reinforced, and in turn was reinforced by, the Chinese Exclusion Cases establishing vast federal power over immigration, and the Insular Cases, upholding extra-constitutional power concerning Puerto Rico and the Philippines. ${ }^{238}$ In the same era that Plessy ข. Ferguson ${ }^{239}$ held that African American individuals could be denied equal rights in white society, ${ }^{240}$ these cases expanded the scope and limited the restrictions on federal power over quasi-sovereign peoples of color.

The Court justified the vast federal power over Indian tribes in explicitly racial terms. In United States $v$. Sandoval ${ }^{241}$ the Court considered whether the Pueblo Indians were Indian tribes over whom the federal government could exercise jurisdiction. ${ }^{242}$ The Pueblos lacked many of the legal indicia previously used to justify federal power: They were arguably citizens of the United States; they farmed and resided in permanent stone dwellings; and, pursuant to Spanish

\footnotetext{
232. 118 U.S. 375 (1886).

233. Id. at 384-85.

234. Id. at 384 .

235. 187 U.S. 553 (1903).

236. See id. at 567 .

237. See DAVID E. WILKINS, AMERICAN INDIAN SOVEREIGNTY AND THE U.S. SUPREME COURT: THE MASKING OF JUSTICE 116 (1997).

238. See Sarah H. Cleveland, Powers Inherent in Sovereignty: Indians, Aliens, Territories and the Nineteenth Century Origins of Plenary Power Over Foreign Affairs, 81 TEX. L. REV. 1, 10-11 (2002) (discussing the links between these cases); Philip P. Frickey, Domesticating Federal Indian Law, 81 MINN. L. REV. 31, 39-48 (1997) (discussing the links between Lone Wolf and the Chinese Exclusion Cases).

239. 163 U.S. 537 (1896).

240. Id.

241. 231 U.S. 28 (1913).

242. See id.
} 
land grants, they held their land in fee simple. ${ }^{243}$ Stripped of a legal basis to differentiate them from other Americans, the Court was forced to turn to racial stereotypes to justify federal power. The Court found that although the Puebloans were "sedentary rather than nomadic" and "disposed to peace and industry," they were "nevertheless Indians in race, customs, and domestic government." living in separate and isolated communities ... and chiefly governed according to the crude customs inherited from their ancestors, they are essentially a simple, uninformed, and inferior people. ${ }^{245}$ The Pueblo was therefore a "distinctly Indian communit[y]" that the federal government could choose to treat as an Indian tribe. ${ }^{246}$

The Court also began to undermine the territorial nature of tribal rights, upholding new exercises of state jurisdiction over non-Indians in Indian country. ${ }^{247}$ The period did see several decisions protective of tribal treaty rights ${ }^{248}$ and jurisdictional rights. ${ }^{249}$ Even these cases, however, often assumed the inferiority of tribal societies, stating that they were allowed such rights of self-government as were "consistent with the safety of the white population ... to encourage them as far as possible in raising themselves to our standard of civilization, ${ }^{, 250}$ referring to tribal law as "red man's revenge" in contrast with "white man's morality," ${ }^{\text {"251 }}$ and justifying even the reservation of water rights as part of a policy of converting Indians from a "nomadic and uncivilized people." Thus these cases, while importantly continuing and affirming principles still

243. Id. at $39,47-48$.

244. Id. at 39 .

245. Id.

246. Id. at 46 .

247. See Utah \& N. Ry. v. Fisher, 116 U.S. 28 (1885) (holding that the territory could tax the railway running through Fort Hill Indian Reservation); United States v. McBratney, 104 U.S. 621 (1882) (holding that Colorado had exclusive jurisdiction over crimes between non-Indians on the Ute Reservation).

248. See Winters v. United States, 207 U.S. 564 (1908) (implying a treaty right to sufficient water to irrigate reservation); United States v. Winans, 198 U.S. 371 (1905) (upholding a treaty right to fish off of the reservation).

249. See, e.g., United States v. Quiver, 241 U.S. 602 (1916) (holding that an exception for federal jurisdiction over crimes between Indians prohibited jurisdiction over the crime of adultery); Talton v. Mayes, 163 U.S. 376 (1896) (holding that the Fifth Amendment did not apply to a Cherokee court trying a Cherokee man); Ex parte Mayfield, 141 U.S. 107 (1891) (holding that a Cherokee man could not be federally prosecuted for adultery with a non-Cherokee woman); Ex parte Crow Dog, 109 U.S. 556 (1883) (rejecting the argument that jurisdiction over crimes between Indians could be implied from a treaty and an agreement with tribe).

250. Ex parte Mayfield, 141 U.S. at 115-16.

251. Ex parte Crow Dog, 109 U.S. at 406.

252. Winters v. United States, 207 U.S. at 576. 
protective of tribal governmental rights, largely did so in ways consistent with a vision of tribes as inferior groups being prepared for assimilation.

Historians also increasingly identified triumph over the Indian tribes as the formative racial and national experience of white America. Between 1889 and 1896, future president Theodore Roosevelt published his six-volume The Winning of the West. ${ }^{253}$ The work portrays the steady westward movement of American population as a "great period[] of race expansion." tried to limit acquisition of Indian land, whether the British in the Royal Proclamation of 1763 or the New Englanders seeking to preserve western lands for the tribes, had shortsightedly stood in the way of the "the destiny of the race." ${ }^{, 255}$ Roosevelt acknowledges and regrets the cruelty to innocent Indians. He also presents certain Indian individuals as among the best of any race, quoting a description of the Seneca Chief Logan as "the best specimen of humanity he ever met with, either white or red,"'256 and describing the half-Scottish, half-Creek Alexander McGillivray as "perhaps the most gifted man who was ever born on the soil of Alabama." ${ }^{257}$ But he has no doubt whatsoever that American domination of the continent and its racial stock was wholly just:

The rude, fierce settler who drives the savage from the land lays all civilized mankind under a debt to him.... [I]t is of incalculable importance that America, Australia, and Siberia should pass out of the hands of their red, black, and yellow aboriginal owners, and become the heritage of the dominant world races. ${ }^{258}$

Frederick Jackson Turner reviewed the first volume of the Winning of the West in 1889, praising it and calling for a history of the "progress of civilization across the continent." 259 Four years later, at the 1893 Chicago World's Fair, Turner delivered the essay that would transform American historiography. Among exhibits contrasting live Indians displaying "varying aspects of fast-disappearing aboriginal life" and children attending a "model" Indian boarding school, Turner presented The Significance of the Frontier in American History. ${ }^{260}$ Turner is less insistent than Roosevelt in describing westward expansion as a racial struggle, but he makes clear that triumph of European American over Indian culture is the defining American experience.

253. ROOSEVELT, supra note 25.

254. 1 ROOSEVELT, supra note 25 , at 2.

255. 3 ROOSEVELT, supra note 25 , at 53.

256. 1 ROOSEVELT, supra note 25, at 205.

257. Id. at 65.

258. 3 ROOSEVELT, supra note 25, at 45-46.

259. Frederick J. Turner, The Wimning of the West, DiAL, Aug. 1889, at 71 (1889) (book review).

260. Robert A. Trennert, Jr., Selling Indian Education at World's Fairs and Expositions, 1893-1904, 11 AM. INDIAN Q. 203, 206-07 (1987). 
At the frontier each generation of European immigrants "strips off the garments of civilization," dons "the hunting shirt and the moccasin," and "shouts the war cry and takes the scalp in orthodox Indian fashion." Eventually, however, "he transforms the wilderness," reenacting the "record of social evolution" and the inevitable "disintegration of savagery ...."262 In this crucible the immigrants were "Americanized, liberated, and fused into a mixed race, English in neither nationality nor characteristics." ${ }^{263}$ Note that neither Roosevelt nor Turner demands Anglo-Saxon purity so long as the white "American" race remains dominant. ${ }^{264}$ Roosevelt writes that in "[n]orthwestern cities I could point out some very charming men and women, in the best society, with a strain of Indian blood in their veins." 265 Policymakers went even further, explicitly supporting intermarriage with Indians as an assimilation tool. ${ }^{266}$ In 1888 , Congress enacted a law providing that Indian women who married white men would thereby become American citizens, ${ }^{267}$ so that their husbands could not gain rights to Indian allotments. The law was intended both to "prevent the marriage or miscegenation of . . . degenerate whites with the Indian squaws," and to "encourage Indians to marry white men and become [assimilated] citizens of the United States." 268 The debate on the law provides a neat summary of the

261. FREDERICK JACKSON TURNER, THE FRONTIER IN AMERICAN HiSTORY 4 (Henry Holt \& Co. 1921).

262. Id. at 4,11 .

263. Id. at 23 .

264. See id. Thus Roosevelt, who winks at the prospect of a little Indian blood within the dominant white race, condemns black slavery for its introduction of an inferior race which threatens to dominate the white stock:

[T] he negro, unlike so many of the inferior races, does not dwindle away in the presence of the white man. He holds his own; indeed, under the conditions of American slavery he increased faster than the white, threatening to supplant him... Slavery is ethically abhorrent to all right-minded men; and it is to be condemned without stint on this ground alone. From the standpoint of the master caste it is to [bel condemned even more strongly because it invariably in the end threatens the very existence of that master caste.

4 ROOSEVELT, supra note 25 , at 28-29.

265. 1 ROOSEVELT, supra note 25 , at $18 \mathrm{n} .1$.

266. See also Maillard, supra note 211, at 362 .

267. See Act of Aug. 9, 1888, ch. 818, 25 Stat. 392 (1888). The act was entitled "An act in relation to marriage between white men and Indian women."

268. 19 Cong. Rec. $6885,6886(1888)$. The reference to miscegenation does indicate the ways that prejudice blocked any integration, even of Indians, that challenged white dominance of the American race. Although Virginia's 1924 Racial Purity Act, (the miscegenation law finally declared unconstitutional in Loving v. Virginia), counted as white those whose descent was Caucasian and one-sixteenth American Indian, it also placed all those with more Indian blood in the nonwhite caregory. Six other states also prohibited marriages between Indians and whites. See STEPHENSON, supra note 12, at 82-83 (listing Arizona, California, Nevada, North Carolina, Oregon, and South Carolina, as prohibiting Indian-white intermarriage). These states were in a distinct minority, as most states did not prohibit Indian-white marriage. See, e.g., Weaver v. State, 116 So. 893, 895 (Ala. Ct. App. 1928) (validating a marriage between a white women and a man of Indian and white 
role of Indians in American society. As "squaws," still tied to their tribes and land, Indians were reviled, and any whites that chose to join with them were "degenerate." ${ }^{269}$ By assimilating through marriage, however, female Indians would become both "women" and "citizens., ${ }^{270}$ As a matter of policy, moreover, so long as white preeminence was preserved, absorption of the original, now conquered, race was a fitting tribute. Echoing Thomas Jefferson, one policymaker observed, "while ten grains of Indian to one hundred of white man might be injurious to the quality of the white race, half a grain to one hundred might supply exactly the element needed to improve it.... What happy result can there be to the lamb, but in absorption, digestion, assimilation in the substance of the lion."271

It is tribal culture, not Indian culture, that is explicitly opposed to whiteness. This is clear in the ceremony upon the assumption of citizenship of Indians who had accepted their allotments:

After the American Indian male renounced allegiance to his tribe, shot
his last arrow, and accepted the plow, the federal official said: "This act
means that you have chosen to live the life of the white man--and
the white man lives by work. From the earth we must all get our
living.... Only by work do we gain a right to the land...."
After the American Indian female renounced allegiance to her tribe,
accepted the work bag and purse, the federal official said: "This means you

descent because neither had black heritage); Free v. State, 194 So. 639 (Fla. 1940) (holding that evidence that a husband was of Indian descent did not invalidate his marriage to a white woman); Scott v. Epperson, 284 P. 19 (Okla. 1930) (noting that a statute prohibiting marriage between whites and those of negro blood would also prohibit marriage between a negro woman and a Creek man); Follansbee v. Wilbur, 44 P. 262 (Wash. 1896) (describing a territorial law prohibiting marriages between white men and Indian women that was repealed in 1868); see also MURRAY, supra note 12, at 14 (noting that by 1950, only five states prohibited Indian-white marriages, although thirty states prohibited black-white marriages and fifteen prohibited Asian-white marriages).

269. 19 Cong. Rec. 6886 (1888).

270. Id. at $6885-86$.

271. PHILIP C. GARRETT, INDIAN CITIZENSHIP (1886), reprinted in AMERICANIZING THE AMERICAN INDIANS, supra note 24, at 61-62. Even the common gender divide, in which alliances with Indian women were an accepted means through which white men could obtain sexual access to cribal virtues, broke down to some extent. Well-known Indian men married white women, including Commissioner Ely Parker, physician Charles Eastman, writer-physician activist Carlos Montezuma, and Antonio Lujan, the Taos Pueblo husband of heiress Mabel Dodge Luhan. See DELORIA, UNEXPECTED PLACES, supra note 29, at 87 . The many movies reiterating the grateful Indian maiden theme were joined by a handful of Indian man-white woman love stories, although these relationships were typically doomed. Id. That such movies were made, however, does not mean they were well received. Of RED DEER'S DEVOTION (1911), Moving Picurre World complained, "While such a thing is possible, and undoubtedly has been done many times, still there is a feeling of disgust which cannot be overcome when this sort of thing is depicted as plainly as it is here." Id. 
have chosen the life of the white woman-and the white woman loves her home. The family and home are the foundation of our civilization., ${ }^{272}$

The Indian can thus live the life of a white man or woman, so long as he or she renounces that which is tribal.

Throughout this period, citizenship was extended on an ad hoc basis as a reward for civilization, given to tribal members disavowing allegiance to their tribes or accepting their allotments, and awarded to Indian women marrying white men. ${ }^{273}$ In 1924, the same year Congress finalized the exclusion of Asians from citizenship, it extended citizenship to all Native Americans. ${ }^{274}$ Although the law provided a legal tool for Indians struggling for legal rights in non-Indian communities, it also symbolized the prevailing notion of American dominance over the Indian tribe.

Despite the advocacy of assimilation, Indians leaving reservations to join the broader community often found themselves shut out of public and social institutions. At times this was part of the general exclusion of people of color under Jim Crow. Ariela Gross documents the ways that officials struggled to categorize Mexicans as either Spanish, and therefore white, or Indian, and therefore colored, to fit them into an established racial taxonomy. ${ }^{275}$ But de jure discrimination was often on distinctly Indian grounds, focusing on the individual's connection with a tribe. Thus in Elk $v$. Wilkins ${ }^{276}$ in 1884, the Supreme Court upheld a Nebraska decision to deny the vote to an Indian man on the grounds that he was not a citizen. ${ }^{27}$ Although John Elk had left the reservation where he was born and severed his ties with the tribe over a year earlier, Indians born in tribal relations were not citizens of the United States, and did not acquire such citizenship automatically upon leaving their tribes. ${ }^{278}$ Citizenship, moreover, had a peculiarly descent-based spin, as seen when the Minnesota Supreme Court upheld the disenfranchisement of an entire

272. See Valencia-Weber, supra note 29, at 349 (quoting and discussing a 1937 Department of the Interior publication).

273. See Elk v. Wilkins, 112 U.S. 94, 100, 104-06 (1884) (listing and discussing various laws and treaties providing for citizenship); Dawes Allotment Act, ch. 119, 24 Stat. 390 (1887) (providing citizenship to Indians who took up allotment, separated from their tribe, and adopted the habits of civilized people); Act of Aug. 9, 1988, ch. 818, 25 Stat. 392 (1888) (providing citizenship for Indian women marrying white men).

274. Revenue Act of 1924, 43 Stat. 253 (1924); see Joseph William Singer, The Stranger Who Resides With You: Iromies of Asian-American and American Indian Legal History, 40 B.C. L. REV. 171 (1999) (reflecting on the juxtaposition of 1924 immigration and Indian citizenship acts).

275. See Ariela J. Gross, "The Caucasian Cloak": Mexican Americans and the Politics of Whiteness in the Twentieth-Century Southwest, 95 GEO. L.J. 337, 346-47 (2007).

276. 112 U.S. 94.

277. Id. at 100 .

278. See id. 
community of mixed-blood men on the Red Lake reservation, finding that although they had "reached a degree of civilization superior to that manifested by many white men," ${ }^{279}$ and were likely the children of citizen fathers, they were also (the court assumed) illegitimate, and therefore took the status of their noncitizen Indian mothers. ${ }^{280}$

We see exclusion on the basis of both color and tribal status in Piper v. Big Pine School District of Inyo County, ${ }^{281}$ a 1924 California Supreme Court decision. The school district had refused to admit California Indian Alice Piper, relying on a state statute providing that in areas within three miles of a federal Indian school Indian children could not be admitted to the general public schools. ${ }^{282}$ The court rejected the school district's argument, holding that because the child and her parents "are citizens of the United States and of this state" and had never "lived in tribal relations with any tribe of Indians or has ever owed or acknowledged allegiance or fealty of any kind to any tribe or 'nation' of Indians, ${ }^{2033}$ it violated the Fourteenth Amendment to deny "admittance to the common schools solely because of color or racial differences without having made provision for their education equal in all respects to that afforded persons of any other race or color. ${ }^{284}$ In a testament to the flexibility of grounds for exclusion, however, the court took pains to affirm the constitutionality of the preceding section of the statute, which provided school districts with the power to "exclude children of filthy or vicious habits, or children suffering from contagious or infectious diseases, and also to establish separate schools for Indian children and for children of Chinese, Japanese or Mongolian parentage. ${ }^{2285}$

Despite the color prejudice many Indians experienced, individual Indian integration was publicly celebrated as another symbol of the triumph of European-American civilization over savagery. Boarding schools took before-and-after pictures of Indian children, first arriving in tribal dress and then arrayed in the trappings of whiteness, and circulated them for eager consumption by organizations in the east declaring themselves Friends of the Indian. ${ }^{286}$ Celebration of Indian assimilation also resulted in access to fora wholly barred to African Americans. Graduates of Indian boarding schools won academic and athletic scholarships to East Coast colleges, facilitating an

279. In re Liquor Election in Beltrami County, 163 N.W. 988, 989 (Minn. 1917) (citing Bem-way-bin-ness v. Eshelby, 87 Minn. 108 (1903)).

280. Id.

281. 226 P. 926, 928 (Cal. 1924).

282. Id.

283. Id. at 927 .

284. Id. at $928-29$.

285. Id. at 928.

286. See Transformation of an Indian, in 2 PRUCHA, supra note 149, plate 48 (1984). 
Indian presence in professional sports that has not been matched since. ${ }^{287}$ The football star Jim Thorpe, the only professional Indian athlete most people can name, was a product of this phenomenon. ${ }^{288}$ Thirty-seven years before Jackie Robinson broke the black-white color barrier in major league baseball, Indians played on both sides in the 1911 World Series. ${ }^{289}$ Native actor-writer-director James Young Deer became the head of a major West Coast studio, ${ }^{290}$ while native opera singers were stars of the New York Metropolitan Opera, ${ }^{291}$ translating the fascination with the "disappearing" ${ }^{1122}$ Indian culture into personal success and artistic influence.

Allotment and Jim Crow both further complicated the relationship between Indians and blacks. Tribal members sought to distinguish themselves from African Americans both to escape the yoke of segregation and to maintain an identity that was distinctly Indian in the face of pressure to assimilate. The Lumbee Indians of North Carolina, for example, began their continuing fight for official tribal recognition in the 1870 s to avoid placement in the state's colored schools and to win the right to establish their own schools. ${ }^{293}$ The division of tribal property among individual tribal members through allotment and claims for deprivation of tribal lands also placed stress on definitions of tribal membership. The Cherokee Nation, for example, began enacting laws to prevent the division of their lands and tribal funds among citizens without Indian blood. ${ }^{294}$ At the same time, sexual relations between Indians and blacks were challenged as illegal in states whose miscegenation laws placed Indians in the same racial category as white. ${ }^{295}$

287. For more on Philip and Ella Deloria, see AMERICAN INDIAN BIOGRAPHIES 141, 143 (Carole Barrett \& Harvey Markowiz eds., rev. ed. 2005). The Deloria academic dynasty began in this fashion. The Lakota anthropologist and ethnographer Ella Deloria, was recruited to Oberlin College from the boarding schools, while her brother Vine Deloria, Sr., father of Philip S. and Vine Deloria, Jr. and grandfather of Philip J. Deloria, Jr., attended St. Stephen's College, later renamed Bard College, on an athletic scholarship before returning home to become an Episcopal minister and Lakota leader. DELORIA, UNEXPECTED PLACES, supra note 29, at 117, 133-34.

288. Id. at 135 .

289. Id. at 227-28.

290. See id. at 93-96.

291. See id. at $184-85,204-07$.

292. BERKHOFER, supra note 77, at 101-02.

293. BiU, supra note 199, at 62. Such distinctions also served white interests: White Democrats may have supported the Lumbee petition for state recognition in part to divert some of the nonwhite vote from the Republican party. Id. at 63.

294. See Red Bird v. United States (Cherokee Intermarriage Cases), 203 U.S. 76, 83 (1906) (describing a 1875 Cherokee law providing that intermarried whites could not become citizens in an effort to prevent loss of land through allotment).

295. See In re Atkins' Estate, 3 P.2d 682 (Okla. 1931) (holding that a marriage between a Creek man and a negro woman was illegal, although their children could be considered legitimate and inherit from their father). 
The emerging movie industry reflected the complexity of perceptions of the Indian. Although film studios quickly began churning out westerns portraying white triumph over brutal Indian tribes, they also made movies romanticizing the noble savage, and even dramatizing the brutality of white massacres of Indians. Many of these movies-with names like An Indian's Gratitude, Dove Eye's Gratitude, Red Wing's Gratitude, and The Mesquite's Gratitude-portrayed the drama of the grateful Indian who turns her back on her tribe to emulate white civilization. ${ }^{296}$ In a more subtle reprise of the military claim that the only good Indian was a dead Indian, there are many good Indians in these movies, but they almost all must die to save white settlements. ${ }^{297}$ These movies reenacted Roosevelt's saga of the racially inferior tribe that might share the virtues of a preindustrialized natural world, but was doomed to disappear in the face of the destiny of the white race.

Equally revealing are the movies that portrayed the dilemmas of integrated Indians in a white world. D.W. Griffith, whose Birth of a Nation positions the Ku Klux Klan as the progenitor of a white American nation, also made dozens of films portraying Native Americans. ${ }^{298}$ One of the first was the 1908 Call of the Wild - The Sad Plight of the Civilized Redman. ${ }^{299}$ The protagonist is the handsome George Redfeather, a Jim-Thorpe-like Carlisle honors graduate and football star. Feted by the white Indian agent Lieutenant Penrose, George falls in love with and proposes to the Lieutenant's daughter Gladys. The studio poster for the film tells us, "You may be sure he is indignantly repulsed by Gladys and ordered from the house for his presumption by her father." ${ }^{300}$ Alone in his room, George realizes the "truth," that he is "good enough as a hero, but not as a husband."301 Recognizing the futility of his struggle to assimilate, George gives in to his "long suppressed nature," "hears [the] call of the wild," and returns to his tribe. ${ }^{302}$ After his tribe later captures Gladys out riding, George is about to wreak his "savage" vengeance on her, until Gladys stays his hand by reminding him of the "call of

296. DELORIA, UNEXPECTED PLACES, supra note 29, at 88.

297. See, e.g., IOLA'S PROMISE (Biograph Co. 1912); THE BROKEN DOLL (Biograph Co. 1910); THE GIRL AND THE OUTLAW (American Mutoscope \& Biograph 1908); see also Jack Temple Kirby, D.W. Griffith's Racial Portrature, 39 PHYLON 118, 123-24 (1978).

298. See Gregory S. Jay, "White Man's Book No Good": D.W. Griffith and the American Indian, 39 CINEMA J. 3,3 (2000); Kirby, supra note 297, at 119.

299. CALl OF THE WILD: SAD PLIGHT OF THE CIVILIZEd RedMAN (American Mutoscope \& Biography Co. 1908) [hereinafter CALL OF THE WILD].

300. Poster: Call of the Wild (American Mutoscope \& Biograph 1908), reprinted in DELORIA, UNEXPECTED PLACES, supra note 29, at 86.

301. Id.

302. Id. 
th[e] Higher Voice" of religion, at which he helps her to remount and sadly watches her ride away. ${ }^{303}$ The lesson?

"Gild the farthing if you will; but it is a farthing still." So it is with the Redman. Civilizarion and education cannot bleach his tawny epidermis, and that will always prove an unsurmountable barrier to social distinction. He may be lauded and even lionized for deeds of valor and heroism, or excellence in scientifics, but when it comes to the social circle-never. ${ }^{304}$

Like George Redfeather, Indians at the turn of the century were caught in a double bind. The denigration and near destruction of the Indian tribe was enshrined as part of the "grandeur of their race's imperial destiny."305 Tribes were not envisioned as governments, but rather as racial groupings fixed at an earlier moment of social evolution. Assimilating those under the thrall of this innate "call of the wild" was a vindication of the white race, and the assimilated Indian was celebrated on the national stage. Individuals who chose to follow the white man's road ${ }^{306}$ however, were blocked by color prejudice and stereotypes of the innately wild Indian. While the national ideology meant that the racial barriers to individual Indians were not as absolute as those faced by other groups, their options were circumscribed both as tribal savages and colored individuals.

\section{TWENTIETH CENTURY INNOVATIONS}

The twentieth century saw two innovations in the racial understanding of Indian tribes. First, there was a short respite from policies that treated tribes as permanently inferior and Indians that chose to remain with them as racially misguided. During the Indian New Deal of the 1930s and 1940s, Indian policy and law recognized that securing wellbeing for native people required respecting their choices to remain with their tribes and culture, and accordingly sought to strengthen tribal governments. At the same time, native people seeking tribal rights self-consciously made claims to a distinct Indian ethnic identity. But in the following Termination Era of Indian policy, old assimilationist arguments were not only renewed, they were fortified by the emerging rhetoric of civil rights for individuals. By ignoring the different bases for Indian oppression and resistance, opponents of tribal equality were able to make the same old arguments in the name of equality itself. The Self-Determination policy that has replaced Termination is characterized by both elements, as support for tribal governments

303. Id.

304. Id.

305. 3 ROOSEVELT, supra note 26 , at 99.

306. Poster: Call of the Wild, supra note 300. 
clashes with efforts to reimpose racial limitations when tribal rights undermine non-Indian expectations.

\section{A. A Brief New Deal-A New Twist on the Old One: 1928-1968}

The assimilationist policy helped sow the seeds of its brief demise in the 1930s. A new generation of native people, educated at federal schools and liberal arts universities, used this education to publicize oppression of the Indian and organize against it. ${ }^{307}$ At the same time, the emphasis on the supposedly disappearing Indian and the attempts to gather information on this vanishing culture generated new interest in, and respect for, tribal traditions. Scholarly trends, including emergence of cultural relativism in anthropology, as well as social scientific documentation of the impact of forcible allotment and assimilation, ${ }^{308}$ also contributed to a new direction in Indian policy.

In 1934, under the direction of Commissioner of Indian Affairs John Collier, the federal government implemented a policy that for the first time sought to strengthen tribes and permit Indians to choose to maintain their tribal ties with dignity. ${ }^{309}$ The Indian Reorganization Act (IRA), the cornerstone Indian New Deal legislation, ended allotment, sought to restore and consolidate tribal territories, provided tribal economic development loans, enhanced Indian preference in the Bureau of Indian Affairs, and sought to facilitate tribal governmental organization. ${ }^{310}$ Felix Cohen, the legal architect of the Indian New Deal, recovered the elements of Indian law that had always, at least formally, recognized the status of tribes as governmental entities rather than racial groups and demanded some measure of respect for those governmental entities. ${ }^{311}$

The policy's architects saw the Indian New Deal as fully consistent with equal rights for individual Indians. The IRA was accompanied by the Johnson-O'Malley $\mathrm{Act}^{312}$ which sought to counter state discrimination against

307. See 2 PRUCHA, supra note 149 , at 782 .

308. The most important of these was the so-called Meriam Report by the fledgling Brookings Institution. See Frank Miller, Introduction, in BROOKINGS INSTITUTION: INSTITUTE FOR GOVERNMENT RESEARCH, THE PROBLEM OF INDIAN ADMINISTRATION, at ix-xiii (1971) (discussing the Meriam Report's history and influence).

309. See 2005 COHEN, supra note 21 , at $1339-40$.

310. Indian Reorganization Act, 48 Stat. 984 (1934). For a critique stating that implementation of this policy imposed alien governmental forms on tribal societies, see STEPHEN CORNELL, THE RETURN OF THE NATIVE: AMERICAN INDIAN POLITICAL RESURGENCE 94 (1988).

311. The most succinct summary of this position, and the underlying structure of Cohen's later work, is found in Powers of Indian Tribes, 1 Op. Solicitor Dep't of the Interior 445, 448-50 (1934). For the lasting embodiment of this vision, see 2005 COHEN, supra note 21.

312. 25 U.S.C. $\$ \$ 452-457(2000)$. 
Indians in the provision of governmental services. ${ }^{313}$ An administration lawyer issued an opinion declaring the unconstitutionality of voting restrictions on Indians who maintained tribal relations. ${ }^{314}$ But these policymakers also recognized that equality for American Indians required governmental rights for Indian tribes. As.D'Arcy McNickle, one of the key players in the Indian New Deal, later declared of Collier, "He was saying that Indians are people, as good as any other people. They love their own values, and they should be allowed to work out their own destinies without being beaten down by superior power. That really is what the argument was all about.",315

The Indian New Deal did not survive the 1940s. World War II brought the rhetoric of individual Indian equality to the nationalism that had always existed in cries for Indian assimilation. ${ }^{316}$ Congressional reports protested against the policy of strengthening Indian tribes. In language reminiscent of Richard Pratt and Carlisle, a 1944 House Report declared:

The goal of Indian education should be to make the Indian child a better American rather than to equip him simply to be a better Indian.... The present Indian education program tends to operate too much in the direction of perpetuating the Indian as a special-status individual rather than preparing him for independent citizenship. ${ }^{317}$

Threatened with denial of funding for Indian programs if he remained in office, John Collier, the Commissioner of Indian Affairs who had been the principal champion of the policy, was forced out of office in $1945 .{ }^{318}$ His departure was followed by those of the other architects of the policy over the next few years. ${ }^{319}$ The way was clear for what became known as the Termination Era.

Under Termination, the federal government pursued a policy of ending its special relationship with Indian tribes and transferring tribal territories to the

313. S. REP. NO. 73-511, at 1 (1934) (discussing the Johnson-O'Malley Act).

314. See 1 Ops. Solicitor Dep't Interior Relating to Indian Affairs 799-801 (1938). Felix Cohen filed amicus briefs on behalf of American Indian associations and tribes as well as brought some of the first cases challenging discrimination against individual Indians, helping to establish the Indian right to vote and receive public welfare and social security benefits. See Arizona ex rel. Ariz. State Bd. of Pub. Welfare v. Hobby, 221 F.2d 498 (D.C. Cir. 1954) (noting in dicta that the Social Security Administration properly refused to approve an Arizona plan that failed to provide for reservation (ndians); Harrison v. Laveen, 196 P.2d 456 (Ariz. 1948) (holding that Indians had the right to vote in Arizona); Acosta v. San Diego County, 272 P.2d 92 (Cal. Dist. Ct. App. 1954) (holding that a reservation Indian was eligible for county welfare relief).

315. 2 PRUCHA, supra note 149 , at 1001 n.14.

316. For one of the first such cries, see Armstrong, supra note 11.

317. H.R. ReP. NO. 78-2091, at 9 (1944), quoted in PRUCHA, supra note 286, at 1001-02.

318. 2 PRUCHA, supra note 149 , at 1004-05.

319. See Felix S. Cohen, The Erosion of Indian Rights 1950-1953: A Case Study in Bureaucracy, 62 YALE L.J. 348, 383 (1953). 
members individually or as shareholders in state chartered corporations. ${ }^{320}$ Despite the huge symbolic impact of termination, only about 3 percent of tribes were terminated, and many of those have now been restored to recognition. ${ }^{321} \mathrm{~A}$ more lasting legal product of the era was Public Law 280, which extended state jurisdiction over Indians on reservations in Alaska, California, Minnesota, Nebraska, Oregon, and Wisconsin, and allowed other states to choose to assume such jurisdiction. ${ }^{322}$

Most relevant for our purposes is the rhetoric of the termination policy. The clarion cry for termination was the need for individual Indian equality. Senator Arthur V. Watkins of Utah, the Chair of the Senate Committee on Indian Affairs and the most important legislative advocate of the termination policy, argued:

In view of the historic policy of Congress favoring freedom for the Indians, ... we should end the status of Indians as wards of the government and grant them all of the rights and prerogatives pertaining to American citizenship.

With the aim of "equality before the law" in mind our course should rightly be no other. . . Following in the footsteps of the Emancipation Proclamation of ninety-four years ago, I see the following words emblazoned in letters of fire above the heads of the Indians-THESE PEOPLE SHALL BE FREE! ? $^{33}$

Despite this rhetoric, some of the key individuals in this Indian freedom program played notable roles in undermining equality for other racialized groups. Dillon Myer, the Commissioner of Indian Affairs who oversaw the beginning of the policy, had directed the relocation and internment of Japanese Americans during the war. ${ }^{324}$ Even more interesting is the role of Senator Sam Ervin in the development of the Indian Civil Rights Act (ICRA), which requires tribes to act consistently with most provisions of the Bill of Rights. ${ }^{325}$ ICRA was not finally enacted until 1968, the beginning of the Self-Determination Era, and reflects

320. See Charles F. Wilkinson \& Eric R. Biggs, The Evolution of the Termination Policy, 5 AM. INDIAN L REV. 139, 152-54 (1977). The selection of tribes for termination was inconsistent and ad hoc: Although termination was supposed to target tribes considered prepared for independence, it appears that many were terminated because they were small, because they were in California or Oregon, or simply because they caught the attention of policy makers. See id. at 146. One of the strangest decisions was to terminate the federal status of those Utes with mixed blood. See 25 U.S.C. $\$ 677$ (d) (2000).

321. See Wilkinson \& Biggs, supra note 320, at 151.

322. Act of Aug. 15, 1953, Pub. L. No. 83-280, 67 Stat. 588 (1953).

323. Arthur V. Watkins, Termination of Federal Supervision: The Removal of Restrictions Over Indian Property and Person, 311 ANNALS AM. ACAD. POL. \& SOC. SCl. 47, 55 (1957).

324. Cohen, supra note 319 , at 389 n. 159 .

325. See 25 U.S.C. $\$ \S 1301-1303$ (2000). 
elements of both policies. ${ }^{326}$ But when Senator Ervin began working on the project in 1961, it was Termination Era legislation, imposing the full panoply of constitutional individual rights on Indian tribal governments and providing comprehensive federal review of tribal actions. ${ }^{327}$

Senator Ervin was apparently deeply committed to the bill, which he saw as correcting part of the nation's injustice to Indian peoples and their unconstitutional treatment at the hands of their tribes. ${ }^{328}$ But there are significant ironies in his championship of the bill. First, although the primary impetus for the hearings on civil rights in Indian country was the multiple complaints of abuse and discrimination by federal, state, and local officials, the bill addressed only violations by Indian tribes. ${ }^{329}$ Even more revealing, Ervin was a celebrated opponent of civil rights for African Americans. The Governor of North Carolina appointed Ervin to the Senate in 1954, just months after the Supreme Court issued its decision in Broun v. Board of Education. ${ }^{330}$ He used his first news conference to attack the decision and the justices who, he said, "wished to recreate our Government in their own images." "311 The senator became "Jim Crow's most talented legal defender," and a man whom "southern apologists praised ... as one of the nation's preeminent constitutional scholars." ${ }^{332}$ In the Senate, Ervin was a leading voice arguing that the Constitution, "the most precious instrument of government the earth has ever known," prohibited the civil rights legislation intended to make real the unfulfilled promises of the Reconstruction Amendments. ${ }^{333}$ In the midst of this battle, his advocacy for Indians allowed him to twit his northern liberal colleagues for ignoring "the minority group most in need of having their rights protected by the national government. ${ }^{1,34}$ Ervin may have been the first to fall

326. In recognition of the central role of religion in Indian governments, for example, the Indian Civil Rights Act (ICRA) does not prohibit establishment of religion. See 25 U.S.C. § 1302(1) (2000); see also Santa Clara Pueblo v. Martinez, 436 U.S. 49, 63 n.14 (1978) (discussing some differences between the ICRA and the Bill of Rights). In a further recognition of the important of tribal resolution of fundamental issues, federal review of ICRA matters is only permitted in habeas cases, those where the petitioner's liberty is at stake. Santa Clara Pueblo v. Martinez, 436 U.S. at 67; see 25 U.S.C. $\$ 1303$ (2000).

327. See Donald L. Burnett, Jr., An Historical Analysis of the 1968 'Indian Civil Rights' Act, 9 HARV. J. LEGIS. 557, 588-89 (1972).

328. See id. at 575 .

329. See id. at $584-89$.

330. See Karl E. Campbell, Senator Sam Ervin and School Prayer: Faith, Politics, and the Constitution, 45 J. CHURCH \& STATE 443, 445 (2003).

331. Id.

332. Id.

333. Id. at 444 .

334. Bumett, supra note 327, at 575 (citing Letter From Lawrence M. Baskir, Chief Counsel and Staff Director, Subcomm. on Constitutional Rights of the Senate Comm. on the Judiciary, to Bennett (March 5, 1970) (on file at the office of the Harvard Legislative Research Bureau)). 
into what is today a familiar category: the policymaker who opposes sovereign rights for tribes on the grounds that they violate civil rights that he supports in no other context. ${ }^{335}$

Although the Termination Era reversed the congressional New Deal policy, the record in the Supreme Court was more mixed. Nineteen fifty-five saw a new low for judicial protection of tribal rights, as the Court held that the Takings Clause did not apply to federal acquisitions of tribal lands unless Congress had formally ratified the tribal property right. ${ }^{336}$ Nineteen fifty-nine, however, saw an even more important success. In Williams v. Lee, ${ }^{337}$ the Court held that state courts had no jurisdiction over a claim brought by a non-Indian against a Navajo couple to enforce a contract entered into on the Navajo Reservation. From an individual racial rights perspective, the decision might be seen as affirming a separate status of a people that are in part racially defined. ${ }^{338}$ But the Court emphasized the ways that the decision was necessary to ensure tribal equality, which rested on governmental rights that did not depend on the racial status of the parties:

There can be no doubt that to allow the exercise of state jurisdiction here would undermine the authority of the tribal courts over Reservation affairs and hence would infringe on the right of the Indians to govern themselves. It is immaterial that respondent is not an Indian. He was on the Reservation and the transaction with an Indian took place there. ${ }^{339}$

At least some of the justices understood the links between Williams and their civil rights decisions. Justice Frankfurter sent Justice Black a note on Williams v. Lee stating that he was "pleased to concur in this indirect affirmation of Broun v. Board of Education." "340 Just as Broum was a landmark decision in the effort to undermine racial limitations on African American individuals, so Williams was a landmark in the effort to reverse the racially inferior position of Indian governments.

It is no coincidence that both decisions came in the same decade. Both African Americans and American Indians had served in large numbers in

335. For a more recent example, see OFFICE OFMGMT. \& BUDGET, supra note 3 (opposing H.R. 505, which seeks to give Native Hawaiians the right to self-governance, on the grounds that it would "divide sovereign United States power along suspect lines of race and ethnicity").

336. Tee-Hit-Ton Indians v. United States, 348 U.S. 272 (1955).

337. 358 U.S. 217 (1959).

338. To be a citizen of the Navajo Nation, one must have at least one-fourth Navajo blood. NAVAJO NATION CODE tit. $1, \S \S 701-703$ (2006).

339. Williams, 358 U.S. at 223.

340. Philip P. Frickey, A Common Law for Orer Age of Colonialism: The Judicial Divestiture of Indian Tribal Authority Over Nonmembers, 109 YALE L.J. 1, 29 n.140 (1999). 
World War II and experienced the novelty of competition in a white arena. ${ }^{341}$ Both groups came back impatient with the limitations placed upon them by the country for which they had risked their lives. ${ }^{342}$ For American Indians, this generated new efforts to resist the restrictions placed on tribes. ${ }^{343}$ Williams $v$. Lee was a product of this movement, in particular of efforts by the Navajo Nation to develop and to assert the independence of its tribal courts. ${ }^{344}$ Nationally, Indian tribes began joining together to pursue their quest for tribal equality. The National Congress of American Indians, the first national supratribal organization focused on tribal survival was created in $1954 .^{345}$

At the same time, Indian people fought the persistent political limitations placed on Indians who maintained their connection with their tribes. ${ }^{346}$ Long after Indians were declared citizens in 1924, several of the states with the largest Indian populations continued to deny Indians the right to vote. ${ }^{347}$ In 1928 , the Arizona Supreme Court held that two Pima Indians residing on the Gila River reservation as "wards of the federal government" were "persons under guardianship" ineligible to vote. ${ }^{348}$ This decision was finally overturned in 1948, when two Mohave-Apache Indians, one of them a World War II veteran, again challenged the restriction. $^{349}$ In 1927, New Mexico had responded to the 1924 Indian Citizenship Act by declaring that all "Indians not taxed" were ineligible to vote, a term that apparently excluded even reservation residents who paid some federal and state taxes. ${ }^{350}$ The legislature finally repealed this provision in 1951, after a 1948 federal court decision declared the law invalid. ${ }^{351}$ In 1956 , the

341. See AlisON BERNSTEIN, AMERICAN INDIANS AND WORLD WAR II: TOWARD A NEW ERA IN INDIAN AFFAIRS 40 (1991) (discussing Indian participation in military service).

342. See 2 PRUCHA, supra note 149 , at 1009.

343. See NAGEL, supra note 29, at 118.

344. See Stephen Conn, Mid-Passage-The Navajo Tribe and Its First Legal Revolution, 6 AM. INDIAN L. REV. 329, 358 (1978) (describing the contribution of Navajo court reforms intended to protect court independence and the Williams decision).

345. See KENNETH R. PHILP, TERMINATION REVISITED: AMERICAN INDIANS ON THE TRAIL TO SELF-DETERMINATION, 1933-1953, at 2 (1999) ("These Native American leaders advocated new forms of self-determination that differed from the melting-pot concept favored by most Euro-Americans.").

346. See TO SECURE THESE RIGHTS, supra note 13, at 40 ("Protests against these legal bans on Indian suffrage in the Southwest have gained force with the return of Indian veterans to those states.").

347. For an excellent summary of postcitizenship efforts to block Indian political participation, see Jeanette Wolfley, Jim Crow, Indian Style: The Disenfranchisement of Native Americans, 16 AM. INDIAN L. REV. 167, 181-202 (1991).

348. Porter v. Hall, 271 P. 411, 417-18 (Ariz. 1928).

349. Harrison v. Laveen, 196 P.2d 456 (Ariz. 1948).

350. MURRAY, supra note 12, at 299; see also Tapia v. Lucero, 195 P.2d 621, 621-22 (N.M. 1948) (remanding despite a stipulation that plaintiffs paid "some state and federal taxes," for factual development of the kind of taxes paid, and "the tribal relationship, laws and customs of these Pueblo Indians").

351. See Montoya v. Bolack, 372 P.2d 387, 390-91 (N.M. 1962) (describing the unpublished 1948 order and the 1953 repeal of prohibition). 
Utah Supreme Court held native people residing on reservations still could not vote because they were not "residents" of the state, rejecting arguments based on Indian citizenship, eligibility for the draft, and payment of taxes. ${ }^{352}$ The legislature finally repealed the restriction in 1957 after the U.S. Supreme Court granted certiorari in the case. ${ }^{353}$ Idaho repealed its constitutional prohibition on voting by "Indians not taxed, who have not severed their tribal relations and adopted the habits of civilization" in $1950 .{ }^{354}$ In 1951, South Dakota repealed the statutory provision that Indians "maintaining tribal relations ... cannot vote or hold office." ${ }^{355}$ In 1960, Minnesota also finally removed the constitutional provision limiting the Indian vote to "[p]ersons of mixed white and Indian blood who have adopted the customs and habits of civilization" and "[p]ersons of Indian blood ... who have adopted the language, customs and habits of civilization, after an examination before any district court of the State, ${ }^{336}$ although it had apparently not enforced the restriction after $1934 .{ }^{357}$

Just as native people were fighting to break the limitations placed on tribes as governments, they were defeating the limitations placed on them as individuals for their decisions to remain with their tribes. In the name of racial equality, the Termination policy had reversed the New Deal support for tribal self-government, and resurrected old habits of treating tribes as racial minority groups to be assimilated into the white mainstream. At the same time, however, native people were building the foundation for a resurgence of tribal rights that is continuing today.

B. Equality and Backlash: 1968 to the Present

By the late 1960s, the Termination policy was moribund. All of the 1969 presidential election candidates opposed termination, and in 1970, President Nixon denounced termination as morally and legally unacceptable, initiating the Self-Determination Policy that has remained the official legislative and executive objective to this day. ${ }^{358}$ Under this policy, over half of governmental services for

352. Allen v. Merrell, 305 P.2d 490 (Utah 1956).

353. See Rothfels v. Southworth, 356 P.2d 612, 613 (Utah 1960) (discussing the history of the repeal).

354. MURRAY, supra note 12, at 118. Idaho left in place, however, the prohibition disenfranchising "Chinese or persons of Mongolian descent, not born in the United States." Id.

355. Id. at 423 .

356. Id. at 231; see also MINN. CONST. art. VII, \& 1, cl. 3, 4 (repealed 1960).

357. See Minn. Op. Atty. Gen. 398 (1934) (opining that any Indian born in the United States who meets age and residence qualifications may vote in Minnesota).

358. Special Message on Indian Affairs, I PUB. PAPERS 564 (July 8, 1970). 
Indians have been turned over to tribal control ${ }^{359}$ while other legislation has enabled tribes to protect their cultural and natural resources ${ }^{360}$ and has furthered tribal economic development. ${ }^{361}$ These measures have gone some way in restoring tribes to the position of governments rather than doomed minority groups. By undermining the power expectations built around the helpless ward status of Indian tribes, however, these changes catalyzed a backlash that uses the rhetoric of race equality in the service of the old racial order.

Cheryl Harris wrote in Whiteness as Property that the privileges of race are a property right that law and policy protects in its holders. ${ }^{362}$ She used the antiaffirmative action cases of the Supreme Court as an example of retrenchment against initiatives that would diminish the economic and social advantage attached to whiteness. ${ }^{363}$ This Article has argued that in the Indian context, the privileges of whiteness are not so much individual superiority-only in certain communities is doing better than the Indian an important part of white individual identity. Rather, in Indian-white relations, whiteness includes the right to dominate and profit from tribal territories without regard for tribal governments. Although Congress has, to varying degrees, pursued the policy of self-determination, the Supreme Court has since the late 1970s acted to protect the privileges of whiteness in Indian law.

An important turning point in this trend was the Court's 1978 decision Oliphant $v$. Suquamish Indian Tribe. ${ }^{364}$ The denigration of tribal governments and the denial of their right to interfere with non-Indian interests has lain at the heart of racism against Indian tribes. But with the New Deal and Self-Determination Eras, tribes were both developing and being encouraged in the development of judicial systems that could speak meaningfully to modern issues and exercise control over tribal territories. As part of this process, dozens of tribes were explicitly asserting jurisdiction over non-Indians on their reservations. ${ }^{365}$ Oliphant, however, held that tribes had never had criminal jurisdiction over non-Indians, finding that "by submitting to the overriding sovereignty of the United States," tribes "necessarily give up their

359. See 2005 COHEN, supra note 21, at 1346.

360. See, e.g., Indian Mineral Development Act, 25 U.S.C. $\$ \$ 2101-2108$ (2000); Native American Graves Protection and Repatriation Act, id. \$§ 3001-3013; National Indian Forest Resource Management Act, id. \$§3101-3120.

361. See, e.g., Indian Financing Act, id. § 1451; Indian Gaming Regulatory Act, id. $\S \S 2701-2721 ; 2005$ COHEN, supra note 21 , at 1314-34.

362. Harris, supra note 48 , at 1713-14.

363. Id. at $1766-77$.

364. 435 U.S. 191 (1978).

365. See Bethany R. Berger, Justice and the Outsider: Jurisdiction Over Nonmembers in Tribal Legal Systems, 37 ARIz. ST. LJ. 1047, 1054-59 (2005). 
power to try non-Indian[s]" except with the authorization of Congress. The case explicitly relied on older images of tribes as "characterized by a 'want of fixed laws [and] of competent tribunals of justice,",366 which could be allowed only such jurisdiction as was "consistent with the safety of the white population. ${ }^{.367}$ The historical understanding of tribal governmental inadequacy had become final, not subject to change in the face of modern circumstances. Despite governmental policies supporting tribal courts and the current state of the courts themselves, the Court would not allow them to intrude on the rights of white citizens (even those who, like Oliphant, got into drunken brawls on reservations and assaulted tribal police officers). ${ }^{368}$

Underlining that the Court was protecting the privileges of whiteness, not citizenship, in the same term the Court decided that tribes had inherent sovereignty to try tribal members, ${ }^{369}$ and that a tribal decision to deny membership to the children of a Santa Clara woman could not be reviewed by the federal court. ${ }^{370}$ Where only Indians maintaining tribal relations were concerned, the Court was willing to accord tribes governmental powers. Oliphant, although couched in terms of individual liberty, was an attempt not to let the shift in racial roles go too far, this time in modern garb.

Like Regents of the University of California v. Bakke, ${ }^{371}$ decided just over three months later, Oliphant has spawned a whirlwind almost, but not quite, destroying tribal judicial and regulatory jurisdiction over nonmembers. ${ }^{372}$ This judicial backlash has largely confined the 1959 Williams v. Lee $e^{373}$ decision to its facts, resulting in the peculiar situation that states lack jurisdiction over activities occurring in Indian country where tribal members are the defendants, but tribes only in limited circumstances have jurisdiction over such activities where non-Indians are the defendants. ${ }^{374}$ This jurisprudence has elided past affirmations of tribal rights as governments with territorial jurisdiction. ${ }^{375}$

This judicial backlash has been accompanied by a popular backlash that also affirms the racial limitations on the tribal role. Although the romanticized noble savage remains a treasured part of popular culture, modern-day

366. Oliphant, 435 U.S. at 210 (quoting H.R. REP. NO. 23-474, at 18 (1834)).

367. Id. at 204 (quoting In re Mayfield, 141 U.S. 107, 115-16 (1891)).

368. See Brief for the United States as Amicus Curiae Supporting Respondents at 5-6, Oliphant v. Suquamish, 435 U.S. 191 (No. 76-5729).

369. See United States v. Wheeler, 435 U.S. 313, 332 (1978).

370. Santa Clara Pueblo v. Martinez, 436 U.S. 49 (1978).

371. 438 U.S. 265 (1978).

372. See 2005 COHEN, supra note 21 , at 224-37.

373. 358 U.S. 217 (1959).

374. See Berger, supra note 365 , at 1067.

375. See Powers of Indian Tribes, 1 Op. Solicitor Dep't of the Interior 445, 448-55, 466-76 (1934) (discussing tribal territorial jurisdiction not limited by ownership of land). 
manifestations of Indian rights are met with less approbation. As tribes assert governmental rights that impinge on the privileges of whiteness, protesters attempt to rerace tribes and their members to undermine those rights. ${ }^{376}$

One of the earlier manifestations of this phenomenon was in the treaty fishing battles beginning in the 1960s. Like many tribes, when the tribes of the Northwest and of the Midwest Great Lakes states ceded land by treaty in the nineteenth century, they preserved their right to hunt and fish in the ceded lands. ${ }^{377}$ In the twentieth century, however, non-Indian commercial overfishing and depletion due to pollution, dam projects, and introduction of invasive species led to increased restrictions on fishing practices. When this regulation resulted in crackdowns on tribal fishing, the tribes fought back, asserting their ancient treaty rights. ${ }^{378}$ For the tribes involved, these battles catalyzed the resurgence of tribal government and cultural identity. ${ }^{39}$

The struggle generated a renaissance of racial attacks on the Indian tribe. Indeed, the district court hearing the Washington cases made the parallels between the tribal struggles and the demand for individual racial equality clear, noting that "[e]xcept for some desegregation cases," in seeking to protect these treaty rights, "the district court has faced the most concerted official and private efforts to frustrate a decree of a federal court witnessed in this century." "380 In the Great Lakes, for example, Indians had been incorporated into the tourism industry as guides, providing wealthy fisherman with indigenous access to the natural world. ${ }^{381}$ Now, however, they were asserting rights to fish free of state regulation that were superior to and, it was asserted, interfered with the rights of sport fisherman. ${ }^{382}$ The affront to the accepted racial-economic hierarchy brought hundreds of protesters to Anishinaabe fishing sites. ${ }^{33}$ As conflict with Indians had throughout history, the dispute resulted in the cheapening of Indian bodies and life. The Northwestern bumper sticker "Can an Indian, Save a

376. See, e.g., Carole Goldberg, Descent Into Race, 49 UCLA L. REV. 1373 (2002).

377. See, e.g., Treaty With the Chippewas, U.S.-Chippewa, art. 11, Sept. 30, 1854, 10 Stat. 1109 (granting the right to hunt and fish); Treaty With the Nisqualli, Puyallup, etc. (Treaty of Medicine Creek), art. 3, Dec. 26, 1854, 10 Stat. 1132 (preserving the "right of taking fish, at all usual and accustomed grounds and stations"); Treaty With the Ottawa and Chippewa Nations of Indians, U.S.-Ottawa-Chippewa, art. 13, Mar. 28, 1836, 7 Stat. 491 (providing a right of hunting "with the other usual privileges of occupancy").

378. See Puyallup Tribe v. Wash. Dept. of Game, 391 U.S. 392 (1968); People v. LeBlanc, 248 N.W.2d 199 (Mich. 1976); People v. Jondreau, 185 N.W.2d 375 (Mich. 1971).

379. See LARRY NESPER, THE WALLEYE WAR: THE STRUGGLE FOR OJIBWE SPEARFISHING AND TREaty Rights 31 (Univ. of Neb. Press 2002).

380. Washington v. Wash. Commercial Passenger Fishing Vessel Ass'n, 443 U.S. 658, 696 n.36 (1979).

381. See NESPER, supra note 379 , at 51,64 .

382. See id. at 70 .

383. See id. at 4. 
Salmon" 384 in the Midwest became signs saying "Spear an Indian: save a walleye" or even "Spear a pregnant squaw, save two walleyes." ${ }^{385}$

In Lac du Flambeau Band of Lake Superior Chippewa Indians v. Stop Treaty Abuse Wisconsin ${ }^{366}$ the federal district court documented the Northern Wisconsin protests. ${ }^{387}$ Protesters used a barrage of racial epithets-_"Tonto," "Redskin," and "timber nigger" ${ }^{388}$ - but also employed insults that recalled tropes of the racialized Indian tribe. They renewed the nineteenth century characterization of tribal members as lazy and dependent on government handouts, referring to the fishermen as "[a]ll you Indians that are on welfare" and "welfare warriors," and stating: "Look at those fat Indians. Eating all the commodities up at Flambeau there. ${ }^{389}$ Reasserting the history of Indian-white conflict, protesters yelled, "You're a defeated people; you are a conquered people," "the only good Indian is a dead Indian," and "Custer had the right idea." ${ }^{390}$ The protesters also challenged the spearers as lacking Indian authenticity, singing "[a] half breed here; a half breed there, ${ }^{391}$ mocking the cultural and religious significance of spearing, and circulating pamphlets stating that Chippewa spearers use spears "mass produced in China and Korea," and outboard motors "manufactured in Japan."392 The district court found that the protests sought to deny the Indians property rights because of their race in violation of 42 U.S.C. $\$ 1982 . .^{393}$ Discarding the evidence of the leader of the protests that he had previously treated Indians well, Judge Barbara Crabb opined, "It is one thing to treat a group well when its members present no economic or personal inconvenience; it is quite another to continue to treat them that way when they have asserted interests in competition with one's own." 394

More recent examples of this truism come from the debates over Indian mascots and casino gaming. In further testament to the strange racial position of American Indians in the United States, Indians were until recently one of the

384. Bruce Barcott \& Stephen Baxter, What's a River for?, MOTHER JONES, May/June 2003, at 44.

385. Lac du Flambeau Band of Lake Superior Chippewa Indians v. Stop Treaty Abuse Wis., 843 F. Supp. 1284, 1289 (W.D. Wis. 1994).

386. 843 F. Supp. 1284.

387. Id. at 1288.

388. Id.

389. Id. at 1288,1290 .

390. Id. at $1288-89$.

391. Id. at 1289 .

392. Id. at 1291 .

393. Id. at $1285-86$.

394. Id. at 1294. 
most popular sports team names. ${ }^{395}$ The use of another racial group-African Americans, Mexicans, or Asians-in this fashion would generate horror in modem America. ${ }^{396}$ But Indian team names and the accompanying stereotypical depictions of native people are justified as honoring native peoples. ${ }^{397}$ This honor is reminiscent of the role of Pocahontas in the racist south. Absorbed within a white American nation, Indian mascots symbolize a pleasurable connection with the romanticized noble savage; when modern day Indians challenge non-Indian use of Indian images, however, they are quickly reduced to racist stereotypes. Efforts to replace Fighting Sioux as the University of North Dakota team name, for example, generated a poster representing Indians as an alcoholic, lazy, and defeated people dependent on government handouts: "If you get rid of the fighting Sioux we get rid of your free schooling," "Drink'em lots o' fire water," "Pay taxes," "Find something better for time [sic] 'like a job," and "You lost the war, sorry."

Protests against tribal casino gaming are particularly interesting, because they draw directly on a racially fixed image of the tribe. ${ }^{399}$ The accepted and honored tribe is poor, traditional, and close to the earth. ${ }^{400}$ By engaging in profitable commercial enterprises, tribes act as modern governments and violate this accepted Indian image. Others challenge the right to game on the grounds that tribal members are not racially Indian enough. As an Indian Law professor in Connecticut, the site of two vastly profitable tribal casinos, I have more than once been asked, "But are they really Indian?" Although the Indian, or more appropriately tribal, status required for eligibility to enter into a gaming compact does not depend on biological race but rather political status as a recognized tribe, ${ }^{401}$ the thrust of these questions is whether the asker would recognize the tribe's members as racially Indian. As one townsperson complained, "more than half [of the Mashantucket Pequots] are predominantly

395. See Christine Rose, The Tears of Strangers Are Only Water: The Refusal of America to Understand the Mascot Issue, 1 VA. SPORTS \& ENT. L.J. 283, 284 (2002) (noting that over 2700 schools had Indian mascots or team names).

396. The only other human beings used as team names-the Boston Celtics, the Minnesota Vikings, the New England Patriots, and the Notre Dame Fighting Irish-are by groups who are, or historically were, largely descended from these people. Outside reservations, however, the teams named Braves, Indians, Redskins, or Scouts, have historically had virtually no native membership.

397. See Nell Jessup Newton, Memory and Misrepresentation: Representing Crazy Horse, 27 CONN. L. REV. 1003, 1010, 1013-14 (1995) (discussing the claim of using Indian team names as a form of honoring).

398. Poster. If You Get Rid of the Fighting Sioux (Mar. 2001) (on file with Univ. of N.D.), available at http://www.und.nodak.edu/org/bridges/images/poster2.jpg.

399. See Cramer, supra note 29, at 314-315.

400. See id. at $319,333$.

401. See 25 U.S.C. $\$ 2710$ (2000). 
African American and the rest are mostly white." ${ }^{402}$ Renee Cramer notes the ways that cultural and racial traits blend in these critiques as the Pequots are also accused of being too successful, and therefore "too White," to be Indian..$^{403}$ The rights of Indian tribes are thus fixed by their race, but efforts to assert those privileges in ways that interfere with white expectations result in challenges to racial authenticity.

Most recently, questions of race and Indian tribes have reached the national stage in a different posture, through the exclusion of descendants of African American slaves by the Cherokee Nation of Oklahoma. As discussed above, members of the Cherokee Nation held African slaves and enacted oppressive slave laws in the period before the Civil War. ${ }^{404}$ After the war, the Cherokee Nation agreed by treaty that former slaves would henceforth become tribal citizens. ${ }^{405}$ During the Allotment Period, the United States created rolls of tribal members; these rolls placed whites who claimed citizenship by marriage on "Intermarried White" rolls, those of Indian appearance or those who could prove Indian ancestry on "Cherokee by blood" rolls, and those of African appearance, frequently even if they possessed Indian ancestry, on "Freedmen" rolls. ${ }^{406}$ The Cherokee Nation has recently amended its Constitution to exclude from citizenship all those who cannot prove descent from the by-blood rolls, thus effectively excluding the few remaining descendants from the Intermarried White rolls as well as many more descendants from the Freedmen rolls. ${ }^{407}$ Although these measures do not exclude those with both African American and Cherokee descent, and many phenotypically black individuals are enrolled tribal citizens, the measures raises the specter of de facto racial discrimination in a powerful way.

A recent comprehensive doctoral dissertation shows that in enacting new restrictions limiting membership to those of tribal descent, these tribes are following the trend of most other tribes who have amended their membership requirements since the $1960 \mathrm{~s} .{ }^{408}$ Although federally influenced requirements of the 1930s were more likely to depend on residence and Indian blood quantum, more recently a number of tribes, seeking to establish historical continuity

402. Cramer, supra note 29 , at 330 .

403. Id.

404. See MCLOUGHLIN, supra note 35, at 31-32 (1983); THE CONSTITUTION AND LAWS OF THE CHEROKEE NATION: PASSED AT TAHLEQUAH, CHEROKEENATION, 1839-51, at 19, 44, 53, 212 (1852).

405. Treaty With the Cherokees, U.S.-Cherokee, art. IX, July 19, 1866, 14 Stat. 799.

406. See Vann v. Kempthorne, 534 F.3d 741, 744 (D.C. Cir. 2008).

407. S.E. Ruckman, Cherokee Freedmen: Tribe Reinstates Citizenship Unil Appeals Finished, TULSA WORLD, May 15, 2007, at A13.

408. See Kirsty Gover, Genealogy as Continuity: Explaining the Grouing Tribal Preference for Descent Rules in Membership Governance, 33 AM. INDIAN L. REV (forthcoming 2009). 
with their tribal ancestors in the face of geographic dispersion and intermarriage of their members, have shifted to a tribal blood standard. ${ }^{409}$ This trend should be seen as an effort to assert and to maintain sovereignty rather than racism, a turn from the racially Indian to the politically tribal.

Although the Cherokee action is part of this trend, there is a powerful argument that racism against African Americans plays a role as well. The measure is entangled with the tribe's own participation in the racist institution of slavery and may reflect the tribe's adaptations to first Southeastern and then Oklahoman racist culture. Thus while a shift to a tribal blood quantum measure alone should not implicate charges of racism, the distinctive history here suggests that sovereignty should not insulate the tribe's actions from scrutiny. Importantly, however, the appropriate avenues for such scrutiny are those generally applicable to sovereigns: First, political pressure while the Cherokee Nation evaluates this issue through its own governmental mechanisms; ${ }^{410}$ and second, federal evaluation of whether the tribe is in violation of its 1866 treaty with the federal government. ${ }^{411}$ If the federal government decides to take action, the appropriate remedies are those familiar from international diplomacy, such as censure, economic sanctions, and refusals to enter into further agreements, rather than imposition of federal membership rules.

We are in a time of shifting racial roles, with tribes no longer fully limited by their inferior Indian status and, for the first time since they were powerful trading partners with the colonists, possessing important negotiating power as governments. Both in law and popular culture, however, there is a resurgence of racialized limitations on the Indian tribe in an attempt to cabin this shift. The Supreme Court attempts to fix tribal jurisdiction by race, limiting it to tribal members only, while popular protest both uses old stereotypes of Indian tribes and attacks the racial authenticity of tribes that challenge establish hierarchies of privilege. The history described in this Article suggests that, despite the new responsibilities sovereignty creates for tribes themselves, non-Indians concerned with racial equality should seek to protect meaningful tribal sovereignty rather than undermine it.

409. Id.

410. Before the constitutional amendment, the Cherokee high court struck down as unconstitutional an ordinance preventing freedmen citizens from voting. Allen v. Cherokee Nation Tribal Council, JAT-04-09 (Okla. Trib. 2006). Since the constitutional amendment, a new suit has been making its way through the tribal courts. See S.E. Ruckman, supra note 407.

411. Legislative measures are largely stayed as a challenge to the measure continues through the courts. Vann v. Kempthorne, 534 F.3d 741 (D.C. Cir. 2008). 


\section{CONCLUSION}

Although history dominates this Article, this history has powerful implications for modern tribal survival. Native nations are in the midst of a cultural and political renaissance. Fueled by the refusal to give up the Indian identities that have sustained them, and supported both by intertribal action and overdue governmental encouragement, modern tribes have reemerged as formidable sovereigns. Development of tribal governments and economies has finally begun to shorten the gap between Indian and white health, education, and standards of living. By interfering with long-established hierarchies of power and non-Indian expectations, however, this renaissance has engendered protests that tribes are not governments but rather racial entities whose rights are fixed by their historic roles. Ironically, this effort to fix tribes in past-subordinate positions has been strengthened by the rhetoric of racial equality.

The history presented in this Article helps reveal that such efforts largely continue past patterns of racialization of native people and Indian tribes. Because civilizing individual Indians formed a central part of the rationale for colonialism, the permanent inferiority of, or need to segregate, the Indian individual was not the dominant expression of racism against Indians. Indeed, the most important racial defect of the individual Indian was the innate urge to cling to the Indian tribe and resist the benefits of assimilation. Tribes, however, were permanently defined by their racial origins. They were representatives of a primitive culture defined by familial ties and inherent habits, rather than modern consent-based governments. As such, they could be denied territory, sovereignty, and many other rights inconvenient with the destiny of the non-Indian, American race. This combination-denigrating the tribe, assimilating the individual - was perfectly tailored to the need to justify colonization yet maintain the moral superiority of Anglo-American identity and democracy. Modern backlash against tribes, which emphasizes the racial composition of Indian tribes and their adherence to insular traditions construed as inferior and unfair, is thus not the product of a society committed to racial equality, but the same old pattern of tribal oppression reshaped for modern ideology.

Shifting our understanding of the role of racism in Indian policy has important implications for equal protection law and its apparently anomalous treatment of American Indians. While classic equal protection jurisprudence can counter discrimination against Indians as individuals, it may pose obstacles to equality for Indians as members of tribes, because tribal membership often 
is, and will likely continue to be, dependent in part on tribal ancestry. ${ }^{412}$ Although the governing precedent upholds special treatment of Indians so long as those measures are "tied rationally to the fulfillment of Congress' unique obligation toward the Indians," thus permitting measures that are "reasonable and rationally designed to further Indian self-government," ${ }^{, 413}$ this precedent is under attack both as a matter of law and of policy. ${ }^{414}$ Understanding that the most devastating manifestations of racism for American Indians were denial of the governmental status of the Indian tribe and limitation of tribal status to that of a racially inferior group provides a new lens to understand why protection of tribal governments is in fact a necessary means to undermine racism toward American Indians.

It also, however, should serve as a cautionary statement to Indian tribes themselves. There are important traditional and contemporary reasons for maintaining descent as a criteria for tribal membership. ${ }^{415}$ But in order to truly act as sovereigns, tribes must consider tribal values of fairness, community, and justice, and reject those measures that do not serve those values. ${ }^{416}$

By examining the ways that race has worked for American Indians, this Article also contributes to a larger scholarly body of work seeking to understand the many manifestations of race in a multiracial America. ${ }^{417}$ In particular, it helps to develop our understanding of the intersection of colonialism and racism, something that American scholars have been slow to incorporate given the forcible separation of African Americans, our archetypical racialized group, from their cultures and nations. ${ }^{48}$ From the moment of racism's emergence in

412. See Carole Goldberg, Members Only? Designing Citizenship Requirements for Indian Nations, 50 U. KAN. L. REV. 437, 446-71 (2002) (discussing the federal pressures and tribal concerns that may support descent-based membership requirements); Gover, supra note 408 .

413. Morton v. Mancari, 417 U.S. 535, 555 (1974).

414. See, e.g., Goldberg, supra note 376 (discussing cases rejecting the application of the Indian Child Welfare Act and implementation of the Reindeer Industry Act to favor Alaska Natives); H.R. 505 POLICY STATEMENT, supra note 3 (opposing strongly a measure to recognize Native Hawaiian sovereignty on the grounds that it "would discriminate on the basis of race or national origin and further subdivide the American people into discrete subgroups according to varying degrees of privilege").

415. Goldberg, supra note 412, at 446-71.

416. See, e.g., Angela R. Riley, Good (Native) Govemance, 107 COLUM. L. REV. 1049 (2007).

417. See, e.g., LAURA E. GOMEZ, MANIFEST DESTINIES: THE MAKING OF THEMEXICAN AMERICAN RACE (2007) (discussing the formation of a Mexican racial identity); FRANK H. WU, YELLOW: RACE IN AMERICA BEYOND BLACK AND WHITE (2002) (discussing the position of Asians in American society); Leti Volpp, Divesting Citizenship: On Asian American History and the Loss of Citizenship Through Marriage, 53 UCLA L. REV. 405 (2005) (discussing the intersections of race and gender in citizenship laws affecting Asian women).

418. See also Laura E. Gómez, Race Mattered: Racial Formation and the Politics of Crime in Territorial New Mexico, 49 UCLA L. REV. 1395, 1399 (2002) ("Typically discussions of race ignore the centrality of colonialism in understanding Mexican, Puerto Rican, Native American, Filipino, Native Hawaiian, and other now-American racial minority groups."). 
early Modern Europe, race was conflated with culture and nation, with an inferior culture implying an inferior biology. ${ }^{419}$ In the United States, this intersection has impacted not only American Indians but other groups for whom the social meanings of race, culture, and nation are fully entangled. Mari Matsuda reminds us that "[f]ear of blackness and oppression of African Americans formed American culture, ${ }^{1420}$ providing a deadly model for the treatment of American Indians along with all other differently raced groups. In the same fashion, the patterns of racialization of American Indian governments and cultures have influenced not only responses to Latin Americans and Asians, but also the cultural demands for "whiteness" that now confront African Americans. ${ }^{421}$

Race, the complex body of social meanings that attach to group differences of ancestry and appearance, has deeply influenced the history and institutions of the United States. Understanding the way that race has worked with respect to American Indians, one of two differently raced groups present throughout the formation of American identity, is thus necessary to understanding and grappling with the history of the United States. Because this history of racialization shaped and continues to impact policy and treatment of American Indians, it is also an important part of the ongoing quest for Indian and tribal survival. This Article, by unpacking and examining the formation and continuing uses of American Indian race, hopefully contributes to both of these goals.

419. See James H. Sweet, The Iberian Roots of American Racist Thought, 54 WM. \& MARY Q. 143, 144 (1997); see also Brooke, supra note 77, at 20.

420. Matsuda, supra note 47, at 170.

421. See Paulette M. Caldwell, A Hair Piece: Perspectives on the Intersection of Race and Gender, 1991 DUKE L.J. 365 (discussing legal and public reactions to traditionally "Black" hairstyles); Devon W. Carbado \& Mitu Gulati, The Law and Economics of Critical Race Theory, 112 YALE L.J. 1757 (2003) (discussing employment discrimination and performative aspects of race). 